\title{
A state-of-the-art review of the fabrication and characteristics of titanium and its alloys for biomedical applications
}

\author{
Masoud Sarraf $^{1,2} \cdot$ Erfan Rezvani Ghomi $^{3}$ (D) Saeid Alipour ${ }^{2} \cdot$ Seeram Ramakrishna ${ }^{3} \cdot$ Nazatul Liana Sukiman $^{1}$
}

Received: 15 April 2021 / Accepted: 24 September 2021 / Published online: 26 October 2021

(c) Zhejiang University Press 2021

\begin{abstract}
Commercially pure titanium and titanium alloys have been among the most commonly used materials for biomedical applications since the 1950s. Due to the excellent mechanical tribological properties, corrosion resistance, biocompatibility, and antibacterial properties of titanium, it is getting much attention as a biomaterial for implants. Furthermore, titanium promotes osseointegration without any additional adhesives by physically bonding with the living bone at the implant site. These properties are crucial for producing high-strength metallic alloys for biomedical applications. Titanium alloys are manufactured into the three types of $\alpha, \beta$, and $\alpha+\beta$. The scientific and clinical understanding of titanium and its potential applications, especially in the biomedical field, are still in the early stages. This review aims to establish a credible platform for the current and future roles of titanium in biomedicine. We first explore the developmental history of titanium. Then, we review the recent advancement of the utility of titanium in diverse biomedical areas, its functional properties, mechanisms of biocompatibility, host tissue responses, and various relevant antimicrobial strategies. Future research will be directed toward advanced manufacturing technologies, such as powder-based additive manufacturing, electron beam melting and laser melting deposition, as well as analyzing the effects of alloying elements on the biocompatibility, corrosion resistance, and mechanical properties of titanium. Moreover, the role of titania nanotubes in regenerative medicine and nanomedicine applications, such as localized drug delivery system, immunomodulatory agents, antibacterial agents, and hemocompatibility, is investigated, and the paper concludes with the future outlook of titanium alloys as biomaterials.
\end{abstract}

\section{Graphic abstract}

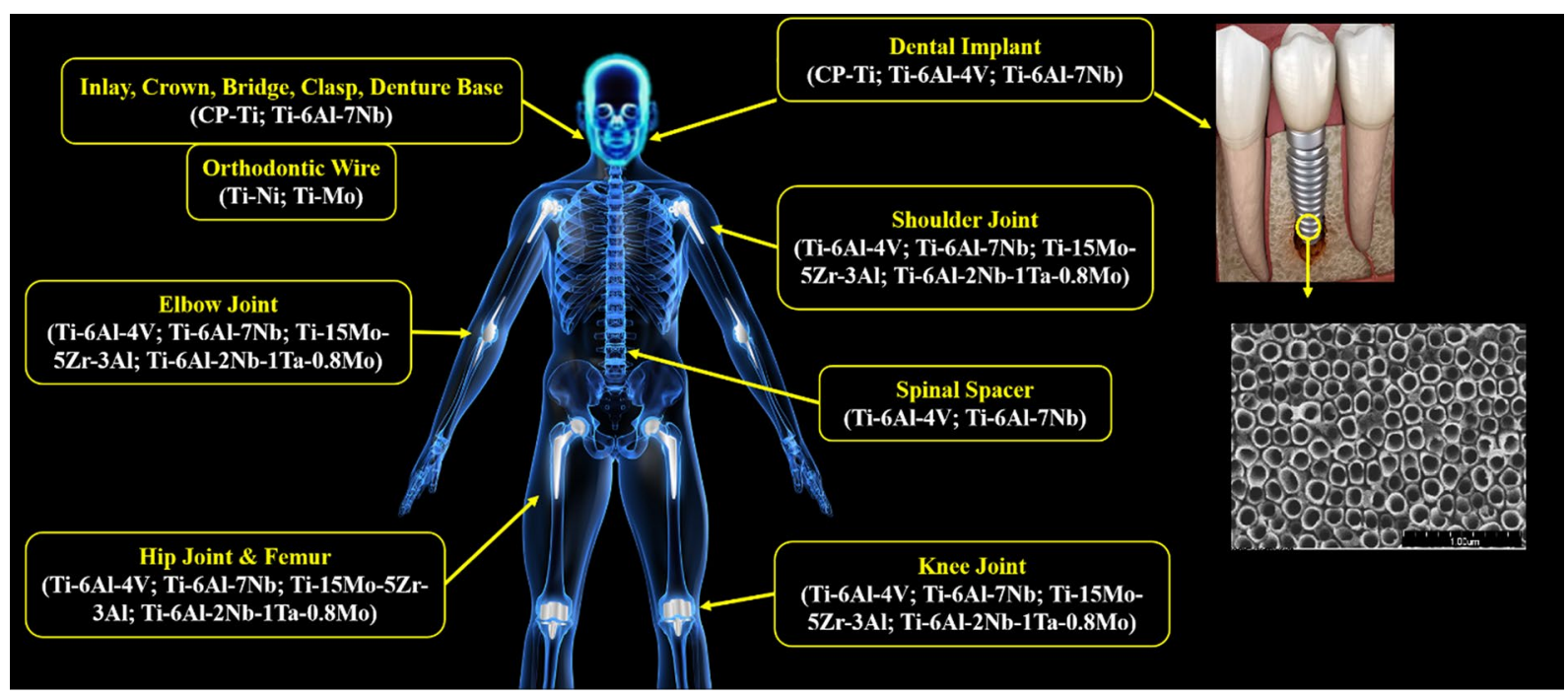

Keywords Titanium and titanium alloys $\cdot$ Biomedical application $\cdot$ Functional properties $\cdot$ Biocompatibility $\cdot$ Antibacterial activity $\cdot$ Advanced manufacturing

Extended author information available on the last page of the article 


\section{Introduction}

In recent years, the number of patients in need of replacing failed tissue with artificial alternatives or implants, such as arthroplasty, hip joints, craniofacial, maxillofacial, dental implants, prostheses, and surgical instrumental applications, has increased [1]. Researchers estimate that demand for the replacement of hip and knee arthroplasties could reach 3.48 billion operations (673\%) in 2030 compared to 2005 in the USA [2]. Therefore, many endeavors have targeted recognizing appropriate biomaterials for the fabrication of durable medical implants [3]. Biomaterials are utilizable owing to their superior mechanical and thermal conductivity properties. The main essential factor for metals to be recognized as biomaterials should be that no adverse reaction occurs when used in the targeted biomedical application; that is, they act as biocompatible materials. Metallic biomaterials are generally utilized for load-bearing applications; thus, they should have adequate fatigue strength. In comparison with ceramics and polymeric materials, using metals as biomaterials and the relevant technologies are continually enhancing because their properties can be modified in the function of the manufacturing processes [4]. Among various types of materials, metallic biomaterials such as $316 \mathrm{~L}$ stainless steels, Co-Cr-based alloys, titanium, and its alloys have desirable properties and hence remain the most adequate choice for replacing failed hard tissue [5].

Grade 316L stainless steels (18Cr-14Ni-2.5Mo wt\%) have been used as implants since the $1920 \mathrm{~s}$. The "L" in 316L stainless steel denotes low carbon content, which can intercept the formation of chromium carbides and increase the corrosion resistance. However, stress corrosion cracking, which cannot be prevented in 316L stainless steel, can be triggered by the combined effect of tensile stress and a Cl-rich environment such as human body fluid, resulting in an undesirable sudden failure of the implant under stresses [6]. Moreover, although Co-Cr-based alloys have a higher corrosion resistance compared to $316 \mathrm{~L}$ stainless steels in human body fluid, some undesirable ions such as $\mathrm{Cr}$ and $\mathrm{Co}$ are released due to wear and corrosion [7]. There have been reports of Co exhibiting carcinogenicity in many animal researches and cases of neurological symptoms in patients after implantation. The released $\mathrm{Cr}$ could affect the blood cells, kidney, and liver by oxidative reactions; therefore, Co-Cr-based alloys and 316L stainless steel have potential risks as implants [8]. Hence, these two alloys may not be the best alternative for orthopedic implants, making titanium (Ti) deserve more attention.

Titanium and its alloys have been used as medical implants due to their long fatigue life, corrosion resistance, high biocompatibility, and lower Young's modulus compared to other implants [9]. Despite the advantages of Ti alloys, supplementary development and modification are essential to devise clinically useful applications. Owing to the inadequate biocompatibility of alloys in this category, which are used in medical implant manufacturing, the risk of implant failure may be enhanced. This may also cause the poisonous agglomeration of ion discharge and wear debris entering the human body. To overcome these drawbacks, different types of advanced manufacturing and surface modification have been proposed [10].

Consequently, it is necessary to conduct comprehensive research on suitable biomaterials like titanium for biomedical applications. The present review focuses on the development of titanium and its multiple biomedical applications, such as bone replacement, dental implants, craniofacial, maxillofacial, surgical instruments, and prostheses. Then, we explore its functional properties, such as biocompatibility, density, corrosion resistance in the biomedical environment, ductility, thermal expansion, yield strength, tensile strength, magnetism, toxicity, host tissue response, protein adsorption, and antibacterial activity. Moreover, we carefully examine the different surface modifications and advanced manufacturing technologies of titanium and its alloys to improve its biomaterial properties. Finally, the applications of $\mathrm{Ti}$ in nanomedicine are discussed along with the future directions of research.

\section{History of development of titanium alloys}

The first reported application of commercially pure titanium (CP-Ti) in medicine originated from 1940, when this metal was found to have excellent compatibility with bones based on results from testing the reaction of bone to multiple metallic implants on animals [11]. During the subsequent decade of the 1940s, achievements made in industrial-scale manufacturing processes for titanium paved the way for an increasing number of studies on the medical applications of titanium [12]. During the 1950s, discoveries were made regarding the compatibility of titanium with soft tissue and the bone of rabbits, as well as its non-cytotoxic properties due to its remarkable corrosion resistance in biological environments, where research on the surgical application of titanium in dogs showed its excellent biocompatibility [13]. Clinical evaluations further confirmed this advantageous characteristic of Ti in long-term animal testing [14]. Subsequently, the utility of CP-Ti was developed through additional clinical reviews of its biocompatibility.

Observations on the long-term medical application of CP-Ti in the human body established that it is prone to fracture in this type of biological environment. However, CP-Ti has currently many applications in the medical field, 
such as an artificial tooth root, internal fixation plates, and mandibular reinforcement plates. Therefore, the safety of long-term applications prompts the appropriate design process for stress conditions [15-17]. Proposals were made to utilize $\mathrm{Ti}-6 \mathrm{Al}-4 \mathrm{~V}$, which is the most widely utilized titanium alloy in the aerospace industry and is an alternative biomaterial for artificial joints and bone fixators [18]. Subsequently, $\beta$-type and $\alpha+\beta$-type titanium alloys possessing low Young's modulus and free of vanadium (V) or aluminum (Al) compounds were developed [19]. A new $\alpha+\beta$-type titanium alloy, $\mathrm{Ti}-6 \mathrm{Al}-7 \mathrm{Nb}$, was created by replacing the vanadium $(\mathrm{V})$ in $\mathrm{Ti}-6 \mathrm{Al}-4 \mathrm{~V}$ titanium alloy with a safer element, niobium $(\mathrm{Nb})$, to reduce the cytotoxicity of titanium and associated alloys [20]. The development of other types of $\alpha+\beta$-type titanium alloys also began during the 1970s using iron (Fe), molybdenum (Mo), and tantalum $(\mathrm{Ta})$, which included $\mathrm{Ti}-6 \mathrm{Al}-2 \mathrm{Nb}-1 \mathrm{Ta}-0.8 \mathrm{Mo}$ and $\mathrm{Ti}-6 \mathrm{Al}-2.5 \mathrm{Fe}$ [21-23].

The advancement of enhancing $\beta$-type titanium alloys for biomedical applications was prolific in the USA and Japan. Different $\beta$-type titanium alloys compounded with elements such as oxygen $(\mathrm{O})$, silicon $(\mathrm{Si})$, and zirconium $(\mathrm{Zr})$ to produce $\mathrm{Ti}-13 \mathrm{Zr}-13 \mathrm{Ta}$ (a near $\beta$-type titanium alloy), $\mathrm{Ti}-12 \mathrm{Mo}-6 \mathrm{Zr}-2 \mathrm{Fe}, \mathrm{T}-15 \mathrm{Mo}$, and $\mathrm{Ti}-15 \mathrm{Mo}-2.8 \mathrm{Nb}-$ $0.2 \mathrm{Si}-0.28 \mathrm{O}$, were developed in the USA. On the Japanese front, $\beta$-type titanium alloys such as $\mathrm{Ti}-15 \mathrm{Mo}-5 \mathrm{Zr}-3 \mathrm{Al}$, $\mathrm{Ti}-15 \mathrm{Mo}-5 \mathrm{Zr}$, and $\mathrm{Ti}-15 \mathrm{Zr}-4 \mathrm{Nb}-4 \mathrm{Ta}$ were formulated [24-30].

The dentistry field has seen successful implementations of CP-Ti from 1965 with the introduction of cast titaniumbase partial denture for use as dental implants, which was based on research establishing the excellent compatibility of titanium with hard tissue [31]. Further advances spurred the use of titanium in dentistry from 1982, when the argon-arc casting machine and magnesia-system investment material were developed following the establishment of multiple dental casting systems utilized in dental restoratives [32].

At the turn of the century, attempts were made to develop novel $\beta$-metastable titanium alloys by designing titanium alloys through transformation-induced plasticity (TRIP) and twinning-induced plasticity (TWIP). The TRIP and TWIP concepts originated from application on steels, which consequently lead to their adaptation to titanium in the form of Ti-Ni shape memory alloy. This opened the future possibility for $\beta$-type titanium alloy with extremely high rates of strain-hardening to be utilized in biomedical applications. In addition to the development of TRIP and TWIP concepts for titanium alloy-based medical devices, extensive research is also being conducted on the design and development of new $\beta$-type titanium alloys as biomaterials for implants based upon the design theory of d-electron [33]. The history of development of titanium alloys for biomedical applications is summarized in Table 1 .

\section{Biomedical applications of titanium alloys}

Titanium and its alloys are widely used in various biomedical treatment scenarios, including arthroplasty and bone replacement, craniofacial, maxillofacial and dental implants, surgical instruments, healthcare goods, or external and internal prostheses. The utilization of titanium alloys in medical devices throughout the entire human body, as well as the specifications of titanium alloys used in medical devices, is shown in Fig. 1.

\section{Arthroplasty and bone replacement}

Titanium is used extensively throughout the whole human musculoskeletal structure. The most prevalent biomedical application of titanium is currently for hip and knee replacements, with shoulder and elbow joint implants following closely. Titanium has also seen frequent utilization in the spinal area for spinal correction parts, spinal fixation devices, spinal fusion cages, and in recent years, replacements of spinal disks $[45,46]$. Rib cages for children made of titanium allow the implant to expand as the body grows, thereby allowing young patients to grow with the rib cage [47]. Finger and toe implants, as well as tibial nails employed in the reinforcement of lower leg fractures, are also made of titanium [48]. Fixation and reconstructive devices that support broken bones, such as bone plates, mesh, pins, screws, and rods made of titanium, are frequently used nowadays [49]. To increase implant lifetime for younger patients, some of these applications utilize roughened bioactive surfaces to limit resorption and stimulate osseointegration.

\section{Craniofacial and maxillofacial applications}

Neurosurgical and cranioplasty applications of titanium include cranial plates, mesh, and acrylic. The biocompatible properties of titanium facilitate faster recovery and reduce the chance of infection. Maxillofacial prosthetics made from titanium alloys with appropriate levels of biocompatibility, strength, and osseointegration are able to stabilize soft tissue prostheses [50]. The application of maxillofacial prosthetics after maxillofacial surgery may often be necessary to restore the patients' cosmetic appearance, their ability to eat or speak and replace any missing facial features due to disease or accident damage [51]. A schematic briefly depicting the design and fabrication process of a patient-specific mandibular prosthetic implant for defects related to maxillofacial clinical applications is shown in Fig. 2.

\section{Dental implants}

Titanium alloys are utilized in restorative dental practice as dental implants, functioning as artificial roots to provide 
Table 1 History of development of titanium alloys for utilization in biomedical applications

\begin{tabular}{|c|c|c|c|c|}
\hline Year & Material & Application & Type of alloy & Reference \\
\hline 1940 & CP-Ti & Compatibility with bones as a metallic implant & $\alpha$ type & [11] \\
\hline 1940 & Ductile Ti & $\begin{array}{l}\text { Launching industrial production and smelting by the Kroll } \\
\text { process for medical applications }\end{array}$ & $\alpha$ type & {$[12]$} \\
\hline 1950 & $\mathrm{Ti}$ & $\begin{array}{l}\text { Compatibility of titanium with soft tissue and the bone of } \\
\text { rabbits as well as the non-cytotoxic properties of titanium }\end{array}$ & $\alpha$ type & [13] \\
\hline 1957 & $\mathrm{Ti}$ & Non-toxicity with long term implantation & $\alpha$ type & [14] \\
\hline 1959 & $\mathrm{Ti}-\mathrm{Ni}$ & Shape memory alloy & $\beta$ type & [34] \\
\hline 1960 & $\mathrm{Ti}$ & Artificial joints & $\alpha$ type & [35] \\
\hline 1970 & Ti-6Al-4V & Orthopedic implants & $\beta$-type and $\alpha+\beta$-type & [36] \\
\hline 1979 & $\mathrm{Ti}-6 \mathrm{Al}-2 \mathrm{Nb}-1 \mathrm{Ta}-0.8 \mathrm{Mo}$ & Surgical implants & $\alpha+\beta$-type & [21] \\
\hline $1970 \mathrm{~s}$ & $\mathrm{Ti}-6 \mathrm{Al}-2.5 \mathrm{Fe}$ & Medical devices & $\alpha+\beta$-type & [37] \\
\hline 1985 & $\mathrm{Ti}-6 \mathrm{Al}-7 \mathrm{Nb}$ & Joint replacement & $\alpha+\beta$-type & {$[38]$} \\
\hline 1996 & $\mathrm{Ti}-12 \mathrm{Mo}-6 \mathrm{Zr}-2 \mathrm{Fe}$ & Surgical implants & $\beta$-type & {$[25]$} \\
\hline 1996 & $\mathrm{Ti}-15 \mathrm{Mo}-2.8 \mathrm{Nb}-0.2 \mathrm{Si}$ & Prosthetic implants & $\beta$-type & [39] \\
\hline 1997 & $\mathrm{Ti}-15 \mathrm{Mo}-5 \mathrm{Zr}-3 \mathrm{Al}$ & Dental casting and surgical implants & $\beta$-type & {$[28,30]$} \\
\hline 1998 & Ti-15Sn-4Nb-2Ta-0.2Pd & Medical implants & $\alpha+\beta$ type & [40] \\
\hline After 2000 & $\mathrm{Ti}-13 \mathrm{Zr}-13 \mathrm{Ta}$ & Implant & $\beta$-type & {$[24]$} \\
\hline After 2000 & $\mathrm{~T}-15 \mathrm{Mo}$ & Biomedical & $\beta$-type & {$[26]$} \\
\hline After 2000 & $\mathrm{Ti}-15 \mathrm{Mo}-2.8 \mathrm{Nb}-0.2 \mathrm{Si}-0.28 \mathrm{O}$ & orthopedic & $\beta$-type & {$[27]$} \\
\hline After 2000 & $\mathrm{Ti}-15 \mathrm{Zr}-4 \mathrm{Nb}-4 \mathrm{Ta}$ & Implant & $\beta$-type & [29] \\
\hline After 2000 & $\mathrm{Ti}-35.3 \mathrm{Nb}-5.1 \mathrm{Ta}-7.1 \mathrm{Zr}$ & Biomedical & $\beta$-type & [41] \\
\hline After 2000 & $\mathrm{Ti}-29 \mathrm{Nb}-13 \mathrm{Ta}-4.6 \mathrm{Zr}$ & Biomedical & $\beta$-type & [42] \\
\hline After 2000 & $\mathrm{Ti}-15 \mathrm{Zr}-4 \mathrm{Nb}-4 \mathrm{Ta}-0.2 \mathrm{Pd}$ & Medical implants & $\alpha+\beta$ type & [43] \\
\hline After 2000 & $\mathrm{Ti}-5 \mathrm{Al}-1.5 \mathrm{~B}$ & Biomedical & - & [44] \\
\hline
\end{tabular}

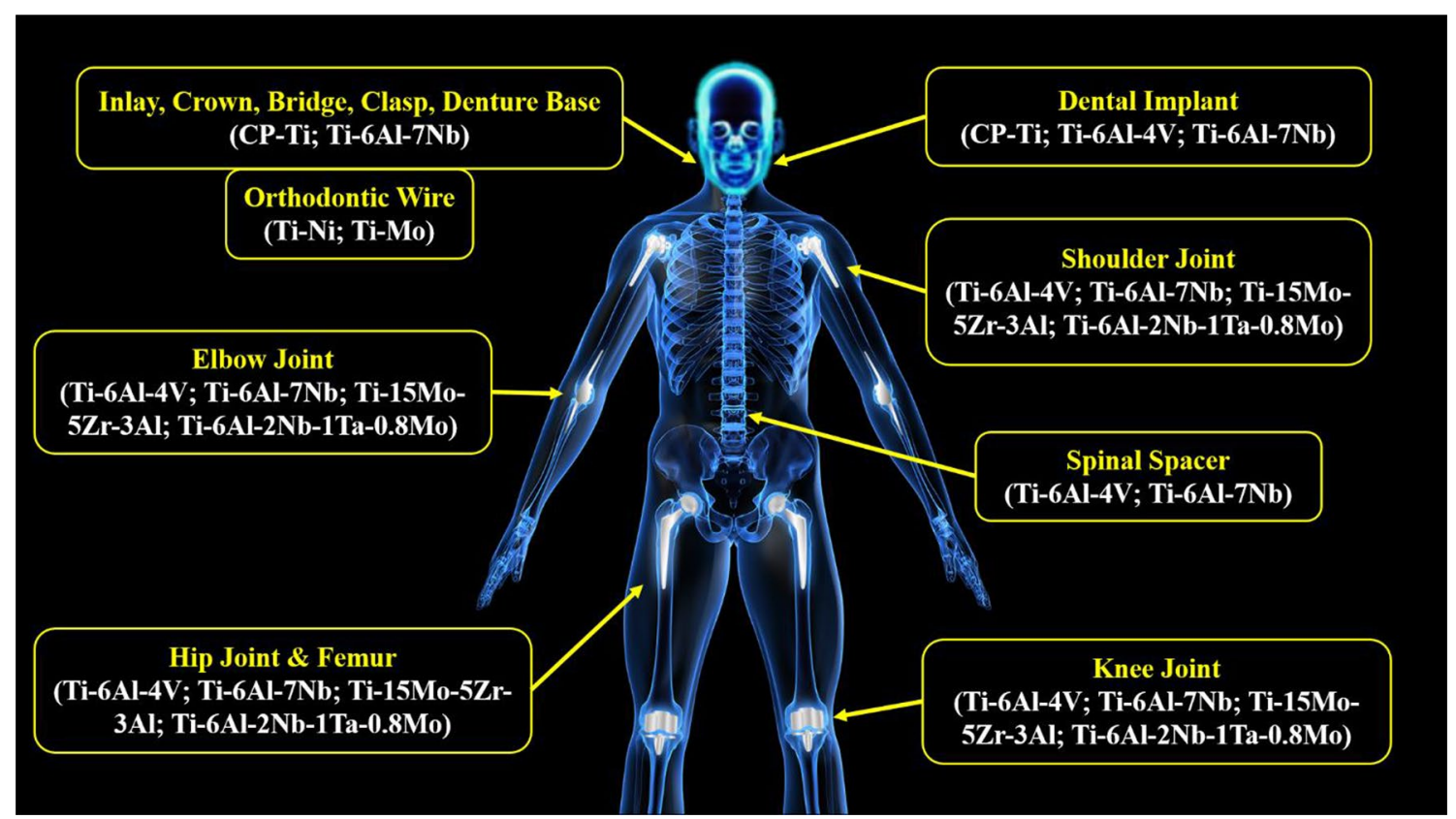

Fig. 1 Titanium alloys used in medical devices throughout the entire human body 


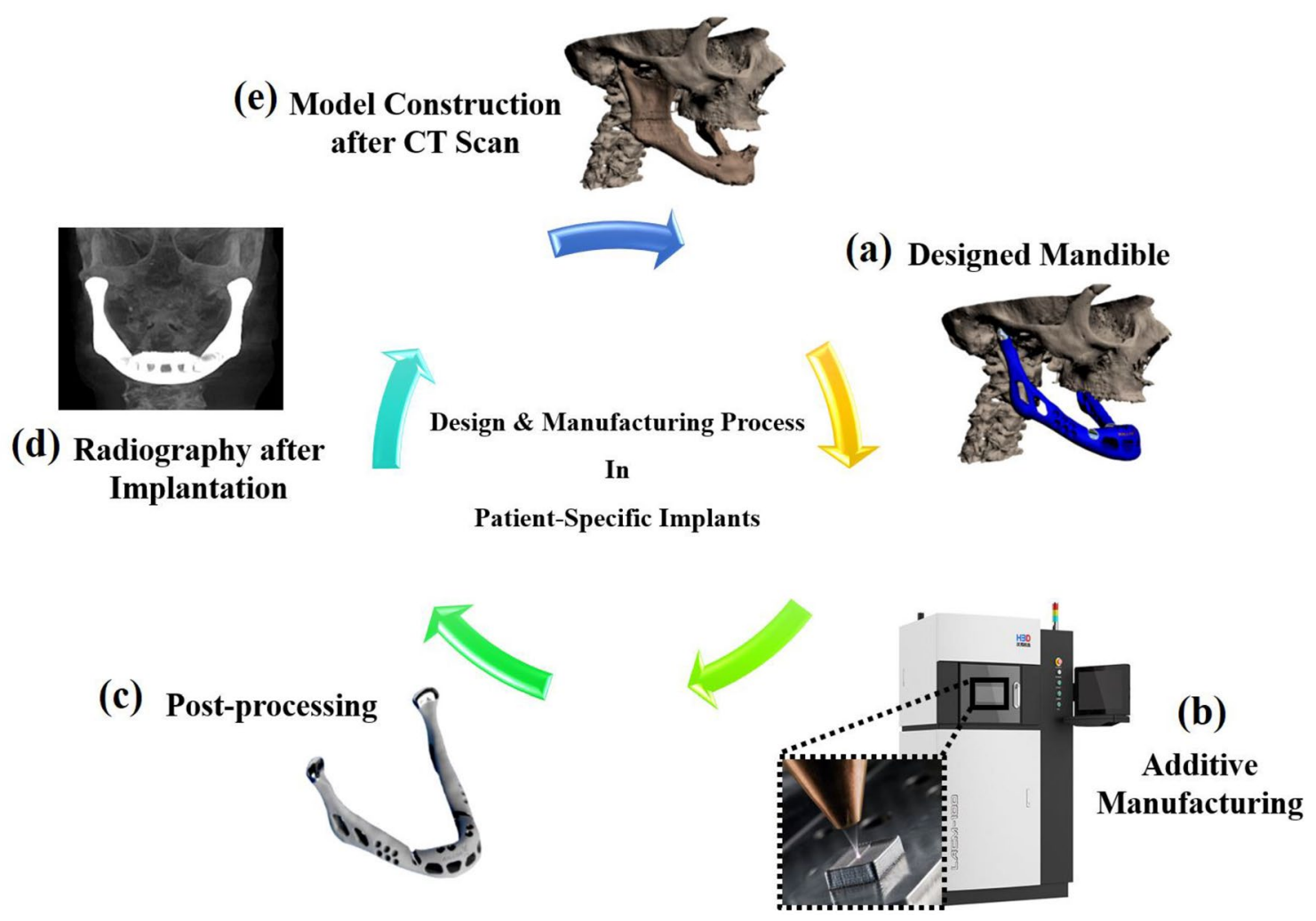

Fig. 2 a-e Brief illustration of the design and fabrication process of a patient-specific mandibular prosthetic implant for defects related to maxillofacial clinical applications

a secure base for a single tooth to a complete dental arch. The titanium dental root comprises biocompatible anchors surgically implanted into the jawbone where the natural tooth is missing to support the artificial crown once the osseointegration period has occurred over time. During this period, the bone grows into and surrounds the titanium implant to create a firm structural support. Thereafter, the higher assembly of tooth superstructure is attached onto the implant as a dental replacement using cementation or the screw-tightening retaining method. Orthodontic braces made of titanium alloys are lighter, stronger, and feature better biocompatibility than steel $[52,53]$. In this regard, pure titanium, $\mathrm{Ti}-6 \mathrm{Al}-4 \mathrm{~V}$, and $\mathrm{Ti}-6 \mathrm{Al}-7 \mathrm{Nb}$ are the primary titanium alloys utilized in surgical and dental applications. The mechanical properties of the various titanium alloys used in dental applications are listed in Fig. 3 [54].

The casting process is instrumental for the dental applications of $\mathrm{Ti}$, with an emphasis on low elongation and high strength [55]. Hydrogenation processing and dehydrogenation processing are efficient techniques to improve elongation without compromising the strength of cast titanium alloys. These include thermochemical processing by postheat treatments such as broken-up structure or $\beta$ and $\alpha-\beta$ solution treatment [56]. Titanium alloys have a higher melting point and are more reactive than other dental alloys, such as $\mathrm{Ag}$ - and Au-based alloys that are preferred for precision dental castings.

\section{External prostheses}

Owing to the inherent properties of titanium, such as corrosive resistance, low weight, and toughness, its alloys are used extensively for the fabrication of temporary or longterm external devices and fixations, including artificial limbs and orthopedic calipers [57-59].

\section{Internal prostheses}

Titanium alloy pegs are used to secure false ears and eyes, while pure titanium grid implants provide fixation for interorbital fractures. The aural applications of titanium include bone conduction hearing aids anchored with devices made of titanium that are connected to the middle ear [60].

The carrier structure for replacement heart valves, coronary angioplasty catheters, defibrillators, intravascular stents, pacemaker cases, and vascular access ports are also made of titanium alloys [61-66]. Infusion pumps utilize titanium-nickel shape memory alloys that flex when the applied electrical current enables the creation of a heating and cooling cycle that changes the shape of the chamber 


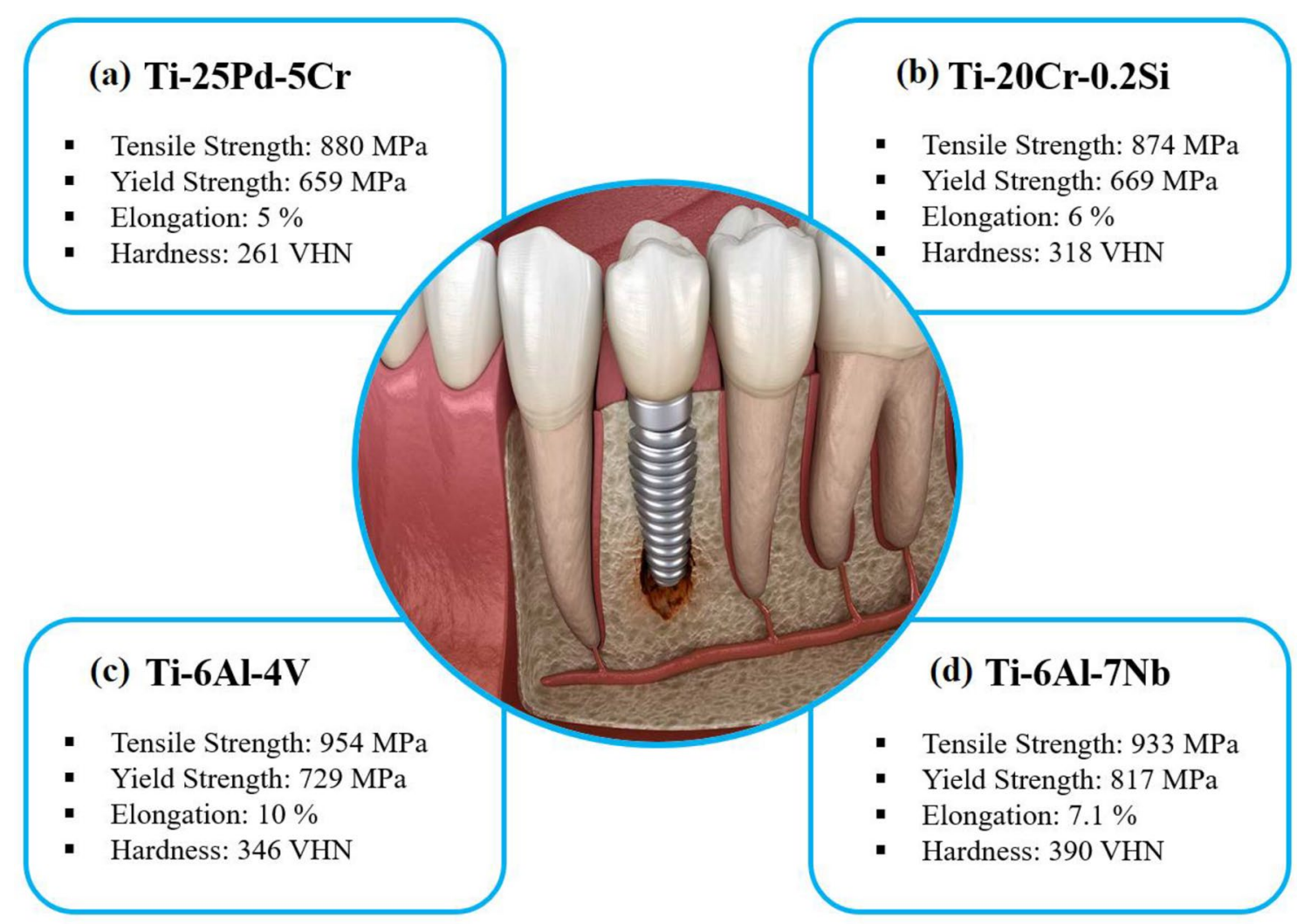

Fig. 3 a-d Various titanium alloys used in dental implants and their associated mechanical properties

[67]. Urethral strictures are treated with urethral stents made from titanium [68].

\section{Surgical instruments}

An extensive range of surgical instruments, such as dental drills, forceps, and laser electrodes, often contain titanium due to its antibacterial properties, resistance to corrosion, compatibility with radiation, durability, and lightweight nature [69]. The low weight of titanium reduces the onset of fatigue for surgeons wielding the instrument for extended periods of time [70]. For microsurgical operations, such as ocular surgery, titanium surgical instruments are usually anodized to produce a non-reflecting surface essential for such operations [70, 71]. The non-magnetic property of titanium reduces the possibility for electromagnetic damage or interference to small and sensitive implants during surgery [72]. The durability of titanium surgical instruments enables them to withstand repeated sterilization cycles without compromising their corrosive resistance, strength, edge quality, and surface quality.

\section{Utilization in healthcare products}

The utilization of titanium alloys for the fabrication of healthcare goods is expanding. Such uses include external prostheses and wheelchairs, particularly those used for sporting purposes, due to their outstanding biocompatibility, low weight, and high-strength properties. The titanium alloys widely used in this aspect are TFCA (Ti-4.0Fe-6.7Cr-3.0Al) and TFC (Ti-4.2Fe-6.9Cr) due to their lower cost than pure titanium, as recycling titanium with iron $(\mathrm{Fe})$ contents, or low-cost ferrochrome $(\mathrm{FeCr})$ can be utilized for this purpose [73, 74].

Even though healthcare goods are not implanted into the patient's body, biocompatibility issues such as allergic reactions still need to be addressed, especially for the elderly who have weaker immune systems and a higher propensity to use these healthcare devices. A study involving pure titanium, Ti-6Al-4V, TFC and TFCA, has shown that TFC and TFCA had greater cell viability among the groups. As such, there is a potential for TFC and TFCA to be used more widely in other types of healthcare goods [75]. 


\section{Functional properties of titanium alloys used in biomedical applications}

Commercially pure titanium possesses several functional properties that are particularly advantageous for various biomedical uses. Here, we explore the characteristics that make titanium a suitable option as a biomedical material for such applications. Table 2 presents the properties of titanium compared to other lightweight metals used in the biomedical field. It can be seen that titanium has a higher melting and boiling point compared to aluminum and magnesium. The demand for biomaterials is related to different parameters based on their applications, such as elasticity modulus; hence, alloys with higher strength have a broader usage in biomedicine [76].

\section{Bio-inertness (inert to chemical reactions with human bodily fluids)}

Decades of medical studies and evaluation performed on titanium as a biomaterial demonstrated its excellent resistance to chemical reactions in the biological environment of the human body under fatigue, stress, as well as in crevice conditions [77]. The bio-inertness property of titanium is the result of its ability to naturally form a protective oxide film under the presence of even trace amounts of oxygen. This protective film is chemically impermeable, highly adherent, insoluble, and prevents chemical reactions between human tissue and titanium under the biological environment of the human tissues [78].

\section{Ductility and malleability}

Pure titanium possesses a relatively high level of ductility and malleability, which allows the use of conventional metal processing techniques and tools to form, machine, and join the biomaterial into functional biomedical implants. Such level of workability enables sheet metal techniques, such as tungsten inert gas welding performed without vacuum, to fabricate biomedical implants with larger and more complex designs [79, 80].

\section{Tensile strength}

Titanium exhibits the highest strength ratio of any metal suitable for medical application as a biomaterial [81, 82]. Titanium is lighter than stainless steel by approximately $56 \%$ but possesses twice the yield strength and an ultimate tensile strength that is approximately greater by $25 \%[83,84]$.

\section{Magnetism}

Titanium is not susceptible to magnetization. Due to its non-magnetic properties, the benefits for patients with titanium inserted into the human body include reducing complications when undergoing CT scan or X-ray, avoiding the magnetization of titanium insert or prosthetic when near an electromagnetic source (such as most modern electronics), and not triggering metal detectors at airports [85].

\section{Density}

Titanium possesses the lowest density among the metallic biomaterials. Matching the density of the biomaterial with that of the already low density of human bone also contributes to the reduction of the stress shielding phenomenon by maintaining the proper distribution of body weight throughout the skeletal structure. Moreover, these properties enhance the image quality produced by computed tomography, magnetic resonance imaging (MRI), and X-ray [86]. Typically, $\beta$-type titanium alloys that have niobium and zirconium elements are utilized in applications where a low modulus of elasticity is required, while $\alpha+\beta$-type titanium alloys are employed in cases where a high modulus of elasticity is required, such as for bone plate.

\section{Corrosion resistance}

Titanium exhibits excellent resistance to corrosion due to the self-formation of a passive titanium dioxide film that protects the metal from further oxidation, thereby inducing low toxicity in comparison with most other biometals. However, the property of corrosion resistance alone is not a determinant of the excellent tissue compatibility of titanium $[87,88]$. The electrical plating of titanium with platinum improves its corrosion resistance at the cost of depleting
Table 2 Physical properties of lightweight metals used as biomaterials

\begin{tabular}{llllllll}
\hline Metallic element & $\begin{array}{l}\text { Boiling } \\
\text { point } \\
\left({ }^{\circ} \mathrm{C}\right)\end{array}$ & $\begin{array}{l}\text { Metal } \\
\text { density } \\
\left(\mathrm{g} \cdot \mathrm{cm}^{-3}\right)\end{array}$ & $\begin{array}{l}\text { Melting } \\
\text { point } \\
\left({ }^{\circ} \mathrm{C}\right)\end{array}$ & $\begin{array}{l}\text { Hard- } \\
\text { ness } \\
(\mathrm{HBW})\end{array}$ & $\begin{array}{l}\text { Elastic } \\
\text { modulus } \\
(\mathrm{GPa})\end{array}$ & $\begin{array}{l}\text { Tensile } \\
\text { strength } \\
(\mathrm{MPa})\end{array}$ & $\begin{array}{l}\text { Thermal con- } \\
\text { ductivity } \\
(\mathrm{W} /(\mathrm{m} \cdot \mathrm{K}))\end{array}$ \\
\hline Titanium & 3289 & 4.512 & 1678 & 716 & 120 & 220 & 26 \\
Aluminum & 2520 & 2.7 & 660 & 160 & 70 & 90 & 238 \\
Magnesium & 1090 & 1.74 & 650 & 44 & 45 & 175 & 156 \\
\hline
\end{tabular}


the bone formation capability due to the surface property of titanium being shielded $[89,90]$. Several studies investigated the corrosion resistance of $\mathrm{Ti}-6 \mathrm{Al}-4 \mathrm{~V}$ and $\mathrm{Ti}-6 \mathrm{Al}-7 \mathrm{Nb}$ in phosphate-buffered saline (PBS) solution. The corrosion potential and current density of Ti-6Al-4V are $-0.143 \mathrm{~V}$ and $4.334 \times 10^{-5} \mu \mathrm{A} \cdot \mathrm{cm}^{-2}$, respectively, and their values are $-0.217 \mathrm{~V}$ and $4.83 \times 10^{-5} \mu \mathrm{A} \cdot \mathrm{cm}^{-2}$ for Ti-6Al-7Nb, respectively, which demonstrated that the corrosion resistance of $\mathrm{Ti}-6 \mathrm{Al}-7 \mathrm{Nb}$ is better than that of Ti-6Al-4V for biomedical purpose. This also results from the fact that niobium has higher corrosion resistance compared to vanadium $[88,91]$.

\section{Resemblance of thermal expansion and elasticity modulus of Ti to human bone}

The coefficient of thermal expansion as well as the modulus of elasticity of titanium closely resembles those of human bone, which in turn significantly reduces the potential for the patient receiving titanium implants to experience stress shielding, as the loads will be comparatively well distributed across the skeletal structure $[92,93]$.

\section{Rigidity of titanium alloys}

Most titanium alloys are designed with low rigidity as the fundamental property for biomedical application as implants and prosthetics [94]. Taking the cortical bone as an example, it is important for the Young's modulus of a biomaterial to be as close as possible to that of cortical bone, as resorption may occur if this value is higher [95]. The $\alpha+\beta$-type titanium alloy Ti-6Al-4V is commonly utilized in biomedicine [96]. Its Young's modulus is lower than that of cobalt-based alloys and stainless steel, but still much higher than that of cortical bone. The Young's moduli of $\beta$-type titanium alloys have been established to be lower than those of $\alpha+\beta$-type or $\alpha$-type titanium alloys, thereby allowing $\beta$-type titanium alloys to feature the required property of low rigidity. Furthermore, these alloys display high strength and outstanding cold workability [97].

The mechanical biocompatibility of titanium alloys with low rigidity for biomedical use was established on rabbits. In the relevant model, an experimental tibial fracture was induced in the tibia beneath the tibial tuberosity through the utilization of an oscillating saw [98]. The fracture was treated with the insertion of an intramedullary rod into the intramedullary canal, which was fabricated from Ti-6Al-4V ELI, Ti-29Nb-13Ta-4.6Zr, or stainless-steel SUS 316L. Atrophy, bone healing, and remodeling were monitored via $\mathrm{X}$-ray imagery every fortnight for a period of 24 weeks. The shape of the fracture callus for $\mathrm{Ti}-29 \mathrm{Nb}-13 \mathrm{Ta}-4.6 \mathrm{Zr}$ was discovered to be very smooth, gradually decreasing from week 6 , and traces of fracture disappearing by week 10 .
Some atrophy change at the posterior of the tibial bone was observed after week 20. Ti-6Al-4V ELI displayed similar results, albeit at a slower rate. For SUS 316L stainless steel, significant fracture calluses were detected that remained until the end of the subsequent period. Observations of the proximal tibial bone at week 10 showed bone atrophy at the posterior part, which became more apparent every fortnight. The posterior tibial bone at week 24 showed signs of the bone structure becoming severely weakened. The low-rigidity titanium alloy $\mathrm{Ti}-29 \mathrm{Nb}-13 \mathrm{Ta}-4.6 \mathrm{Zr}$ has therefore shown a potential to address the load transmission issue faced by current implants $[99,100]$.

\section{Elasticity and shape memory of titanium alloys}

$\mathrm{Ti}-\mathrm{Ni}$ is a shape memory titanium alloy used extensively in the wider industry beyond the field of biomedicine. In fact, $\mathrm{Ti}-\mathrm{Ni}$ has seen limited biomedical applications due to its significant $\mathrm{Ni}$ content, which causes high rates of allergy. However, Ti-Ni has the potential for applications as catheters or stents where shape memory and superelastic properties are desirable [101]. To address the issue of metallic allergy due to the high Ni content, ongoing research and development have been underway for non-toxic titanium alloys with shape memory as well as superelastic properties.

A $\beta$-type titanium alloy known as "Gum Metal" (also called TNTZ) has a similar chemical composition to $\mathrm{Ti}-\mathrm{Nb}-\mathrm{Ta}-\mathrm{Zr}$ system titanium alloys utilized in biomedical applications and has been used as flexible glass frames. Modifications to the chemical composition of "Gum Metal" may enable its potential for biomedical use. The superelastic feature of $\mathrm{Ti}-29 \mathrm{Nb}-13 \mathrm{Ta}-4.6 \mathrm{Zr}$ has been established for biomedical application with reports describing the very low density of dislocations post-deformation [102]. Developments are ongoing for $\mathrm{Ti}-\mathrm{Nb}-\mathrm{Sn}$ system titanium alloys as shape memory Ni-free titanium alloys for biomedicine [103]. Research and development on various $\beta$-type system titanium alloys for biomedical use, such as Ti-Mo-Ga, Ti-Mo-Ge or Ti-Mo-Al, Ti-Ta, Ti-Ta-Zr, and Ti-Sc-Mo, have also been intensive [104-108].

\section{Bioactive surface treatments}

Titanium alloys are generally treated with bioactive surface modifications to enhance their biocompatibility. Despite demonstrating superior biocompatibility in comparison with their metallic counterparts for biomedical use, titanium alloys exhibit similar bio-inertness to ceramics such as alumina and zirconia. Therefore, bioactive materials including phosphate calcium $(\mathrm{CaP})$, $\beta$-CPP $\left(\beta\right.$-Ca2P2O7), and $\beta$-TCP $\left(\beta-\mathrm{Ca}_{3}\left(\mathrm{PO}_{4}\right)_{2}\right)$ coatings are applied on the titanium alloy surface to facilitate the 
formation of hydroxyapatite (HAP). The various bioactive surface modification processes are categorized into dry or wet processes [109-111].

Dry processes consist of direct and indirect HAP forming methods. The former includes the ion beam dynamic mixing method, ion plating, the plasma spray method, the pulse laser deposition method, the superplastic joining method, and radio frequencies (RF) magnetron sputtering, whereby the formation of HAP occurs directly on the surface of the titanium alloy [112-116]. Indirect HAP forming methods include calcium ion implantation, in which calcium alloys are incorporated into titanium alloy, and the calcium ion mixing method where calcium is deposited on the surface of titanium alloy, followed by the implantation of argon ion. These treatments enhance the precipitation of phosphate calcium on biomedical titanium alloy surfaces [117].

In a similar manner, wet processes consist of direct and indirect HAP forming methods. Electrochemical treatment is a direct HAP forming method, while alkali treatment is an indirect HAP forming method that involves heating the titanium alloy during immersion in sodium hydroxide solution $(\mathrm{NaOH})$, followed by immersion of the said titanium alloy in simulated body fluid [118, 119]. In addition, several other methods have been applied to form an apatite layer on the $\mathrm{Ti}$ surface in simulated body fluid (SBF) for various biomedical applications, as follows: $\mathrm{NaOH}$ and heat treatments; $\mathrm{NaOH}$, $\mathrm{CaCl}_{2}$, heat and water treatments; $\mathrm{H}_{2} \mathrm{SO}_{4} / \mathrm{HCl}$ and heat treatments; $\mathrm{NaOH}$, and acid and heat treatments [120].

\section{Biocompatibility of and host tissue responses to titanium alloys}

\section{Host tissue response}

Observations on the structural interface located between the titanium biomaterial and bone tissue both at the microscale and the nanoscale facilitate the understanding of the osseointegration mechanism. The titanium substrate is covered by several layers of materials in the following order: titanium oxide with a thickness of a few nanometers; an amorphous layer of proteoglycans with a thickness of $20-50 \mathrm{~nm}$; a slim layer of cells; a region with mild calcification; and bone tissue. Researchers have recently investigated the reaction mechanisms contributing to the capability of titanium for osseointegration. The influencing factors found include effects of healing and immune modulation; hydrophilicity and wettability; increase in gene expression associated with angiogenesis, neurogenesis and osteogenesis; inflammation-immunological balance; interactions between platelets and red blood cells; and molecular signaling mechanisms related to immune osteocytes [121-123].

\section{Surface hydroxyl groups}

The properties of the surface oxide film covering the titanium substrate govern reaction mechanisms at the interface located between the titanium biomaterial and living tissue. Hydroxyl groups are formed on the surface oxide film due to interactions with moisture from the air, which in turn form electric charges after dissociating in aqueous solutions, such as bodily fluids. The $\mathrm{pH}$ of the surrounding solution determines the value of the electric charge, which becomes zero at a certain $\mathrm{pH}$ value. This $\mathrm{pH}$ is also called point of zero charge (PZC) that is dependent on the oxide and is an indicator showing acid or base property. In the case of titanium oxide, the PZC of anatase is 6.2 , while that of rutile is 5.3, which translates to an almost neutral property that is neither significantly acidic nor basic. The concentration of surface hydroxyl groups on titanium oxide, at $4.9-12.5 \mathrm{~nm}^{-2}$, is relatively large $[121,124]$. This large concentration or wettability increases post-immersion in an aqueous solution, which promotes the absorption of proteins such as cytokines and integrins.

\section{Protein adsorption}

Since proteins carry charges depending on the $\mathrm{pH}$ environment, their conformation is altered via adsorption onto the biomaterial surface. The relative permittivity of the surface oxide film determines the electrostatic force between proteins and the metal surface; that is, a larger relative permittivity translates to a smaller electrostatic force. Titanium oxide has a relative permittivity of 82.1 , which is similar to that of water at 80.0 and is significantly larger than that of other oxides. Thus, the conformational fluctuations of protein adsorbed on titanium oxide are comparatively small. The absorption layer for fibrinogen is thicker, though the absorption amount in aqueous solution is smaller on titanium than on gold. Titanium is covered with $\mathrm{TiO}_{2}$, whereas gold is an exposed metal without surface oxide; hence, the electrostatic force for titanium is much smaller than that for gold. Therefore, the change in protein conformation is smaller on titanium, and proteins adsorbed on titanium are less susceptible to conformational changes compared with those adsorbed on gold [125, 126].

\section{Formation of calcium phosphate}

While the surface oxide film is macroscopically stable, its chemical state and composition vary based on the surrounding conditions. The composition of surface oxide film continuously changes based on the environment; from a microscopic viewpoint, it participates in a constant cycle of partial dissolution and reprecipitation in the electrolyte. In a biological environment, calcium phosphates easily 
form on the surface of titanium and titanium alloys, while under cell culture, they form sulfite and sulfide, respectively. The $\mathrm{Ca} / \mathrm{P}$ atomic ratio to stimulate the generation of a bone-like apatite layer is considered as a key feature for rapid bone rehabilitation. Titanium is stabilized following calcium phosphate formation with a $\mathrm{Ca} / \mathrm{P}$ atomic ratio of around 1.6 when soaked in Hank's solution, which is close to the stoichiometric molar ratio of hydroxyapatite. Furthermore, phosphorous and calcium can be detected at the interface located between the titanium biomaterial and bone tissue. The capability of titanium to form calcium phosphate is one of the contributing factors to its outstanding hard-tissue compatibility $[127,128]$.

\section{Osseointegration}

For a patient's body to successfully accept the biomedical implant, it is instrumental to establish safe implant placement and shorten the postoperative healing period, as the human body will begin to reject the implants after a response to osseointegration for a minimum period [129, 130].

Due to the high dielectric constant of its surface oxide, titanium possesses the capability to form a direct interface with and bond well to living bone tissue without intervening soft tissue. This high dielectric constant does not denature proteins when titanium biomedical implants are inserted into the body. Such functional ankylosis enhances the durability and mechanical stability of load-bearing titanium implants as compared to biomaterials that require the use of adhesives, as the amount of force required to break the physical bond formed between the human bone and titanium inset is considerable [129, 131]. However, according to other researches, in early implementations of implants into the human body made of CP-Ti, the surface of the biomaterial is unable to integrate with the patient's bone due to the bioinert surface property of titanium $[132,133]$. This leads to a longer healing duration and occasionally the surface encapsulation of the implant over time. The possible consequences are the loosening of the implant, the formation of wear debris or fibrous tissue developing at the implant site, micromotion, and the possibility of fracture or delamination at the implant-bone interface [134, 135].

The key factors that determine the successful osseointegration of implants include biological compatibility in that the implant is not toxic to the surrounding living tissues, mechanical compatibility in that the implant is able to transfer stress loads between the receiving living tissue and the root of the placed implant, and morphological compatibility in that the implant is able to promote bone cell growth at the implant location [136, 137].

\section{Strategies to enhance the antimicrobial properties of titanium alloys through ultraviolet (UV) irradiation}

The surface of pure titanium shows signs of decreased histocompatibility over time. The application of UV irradiation reverses the effects of the biological aging phenomenon through the physiochemical alteration of the titanium surface, a process known as photo-functionalization [138]. Titanium implants used in dental surgery are sterilized via UV irradiation [139]. In addition, there is potential in exploring the antibacterial effects of UV irradiation on orthopedic biomaterials typically comprised of titanium alloys, including Ti-6Al-4V. Accordingly, evaluations have been performed on the antimicrobial and bactericidal effects of UV irradiation, at a shorter and lower dosage than in prior applications, to treat $\mathrm{Ti}$ and titanium alloy Ti-6Al-4V for utilization in implant surgery [140, 141].

Postoperative infections involving the use of metallic biomaterials comprise a significant complication for patients. Thus, multiple studies have attempted to develop methodologies that can alter the surface of implants to prevent or reduce the initial bacterial adhesion. These alterations are based on the principle of hindering the ability of microorganisms to form biofilms by enabling the patient's cells to attach to the implant surface first. Pure $\mathrm{TiO}_{2}$ substrates with photocatalytic properties have been demonstrated as capable to function as disinfectants and eliminate organic compounds when exposed to UV irradiation $[142,143]$. Prior studies have shown the bactericidal effect of Ti-6Al-4V alloy surface exposed to UV subtype UV-C light at $227 \mathrm{~J} / \mathrm{cm}^{2}$ dosages for $15 \mathrm{~h}$. Studies have also indicated that exposing Ti-6Al-4V alloy to UV irradiation at lower duration and energy induces increased bioactivity and osteoconduction. However, the dimensions of the implant are typically determined perioperatively, which leads to challenges in preparing the implants by UV irradiation before surgery. The difficulties experienced in the perioperative replication of the aforementioned antimicrobial strategies in clinical practice involving total implant surgeries have led to the conclusion that it is necessary to evaluate the antimicrobial and bactericidal effects of exposing $\mathrm{Ti}$ and $\mathrm{Ti}-6 \mathrm{Al}-4 \mathrm{~V}$ to UV irradiation of shorter durations and energy levels [140].

Based on previous knowledge, one study investigated how UV irradiation contributes to the antimicrobial effect, which involved seeding Staphylococcus aureus 834 bacterial suspensions onto $\mathrm{Ti}$ and $\mathrm{Ti}-6 \mathrm{Al}-4 \mathrm{~V}$ disks that had been exposed to a $9 \mathrm{~J} / \mathrm{cm}^{2}$ dosage of UV light for a period of $15 \mathrm{~min}$. The evaluation of the bactericidal effect of UV irradiation involved seeding the bacteria onto the disks at different time points after UV irradiation under the 
same conditions. The time periods were $0,0.5,1,6,24$, and $48 \mathrm{~h}$, followed by 3 and 7 days. After harvesting and culturing the bacteria, the colonies were counted in both groups. Findings showed the absence of colonies on the UV-irradiated disks after seeding the bacteria. After the addition of bacteria onto the UV-irradiated disks, the number of live bacteria initially decreased before showing a steady rise. However, the antimicrobial effect faded over time [140].

The conclusive results showed that UV-irradiated Ti and Ti-6Al-4V exhibited similar antimicrobial properties, the bactericidal effect was maintained for a week post-UV irradiation on both disks, and this effect was similar on both types of disk. In addition, low-energy and short-duration UV irradiation was determined to contribute to the bactericidal effect on both Ti and Ti-6Al-4V [140].

\section{Surface modifications of titanium}

The detailed description of the surface properties of the biomedical implant, such as its surface morphology, structure, and chemistry, is critical to determine the reactions between the biomaterial implanted into the body and the associated live tissues [144]. The biocompatibility of a biomaterial is typically improved via modifying its surface properties through a combination of biochemical coatings and morphological changes. The main aim of these surface modifications performed on implants is to avoid foreign body response, decrease bacterial adhesion and inflammatory reaction, as well as increase implant integration and tissue adhesion [145].

Biocompatibility has shown to be dependent on the interrelation of various factors influencing the bulk and surface properties of biomaterials, which include surface topography (e.g., surface roughness), surface chemistry (e.g., surface tension and purity for wetting), and nature of tissue integration (e.g., fibrous, osseous, or mixed) [146-148].

Roughness modifications commonly applied to titanium and titanium alloys can yield significant improvements in biomedical performance without compromising the bioinert nature of these materials. Furthermore, chemical modifications may be required to ensure rapid osseointegration. These include deposition methods, such as precipitating calcium phosphate through immersion into synthetic body fluid, electrodeposition, protein absorption, and plasma spray $[149,150]$. Alternatives to chemical modification have also been developed, such as the biomolecular functionalization of implant surface with various biomolecules, including collagen, fibronectin, peptides, as well as bioengineered protein fragments. Regardless, the critical mechanism involved pertains to how the bioactive molecule binds to the surface of the implant, as well as the method of immobilization [151-153].

The host environment has been reported to have the most significant influence on the biomaterial-to-tissue interface zone, where the interaction occurs between the implanted biomaterial and recipient tissues. This interface zone, which involves the implant surface layer and several nanometers into the recipient tissues, determines the circumstances of healing, as well as the clinical longevity of the implant's load-bearing function [121].

The mechanical methods generally used for titanium and titanium alloys to obtain rough surfaces are subtraction processes, such as blasting, grinding, machining, and polishing, while smoothing the surfaces requires attrition processes, such as milling. The objective of such mechanical modifications is to produce a surface with specific topographies for improved adhesion in bonding while cleaning or roughening the surface, since the increased surface roughness of the implant structure is deemed more conducive for biomineralization [154, 155].

Chemical methods, such as acid and alkaline etching, biochemical surface coating methods, chemical deposition, and electrochemical anodization, are generally utilized to provide titanium and titanium alloys with bioactive surface characteristics. The aim is to improve bioactivity, biocompatibility, corrosion resistance, and osteoconduction and remove any contaminations. Obtaining irregular morphologies for titanium implant surfaces on the nanoscale can be achieved through a multitude of chemical methods, while electrochemical anodization is generally used when the aim is to fabricate controlled nanostructures, such as nanodots, nanorods, and nanotubes [156-158]. The fabrication process of titanium dioxide nanotube (TNT) arrays by anodization is shown in Fig. 4.

Physical surface modification methods do not require chemical reactions to produce the desired engineered surface. Such methods include glow discharge plasma treatments, ion implantation, physical vapor deposition, and thermal spraying. The resulting layer of coating or film formation on the surface of titanium substrate is simply a product of transferring various types of energy, such as kinetic, electrical, or thermal, which is unique to each method [159-161].

\section{Titanium/silver physical vapor deposition (PVD) coatings}

The formation of biofilm and endoprosthesis infection are regular issues pertaining to complications of implant surgeries. Adjustments to the implant surface prior to implantation have been applied to overcome such postoperative infections. One of the techniques for surface modification to improve the biocompatibility and antimicrobial properties of titanium 


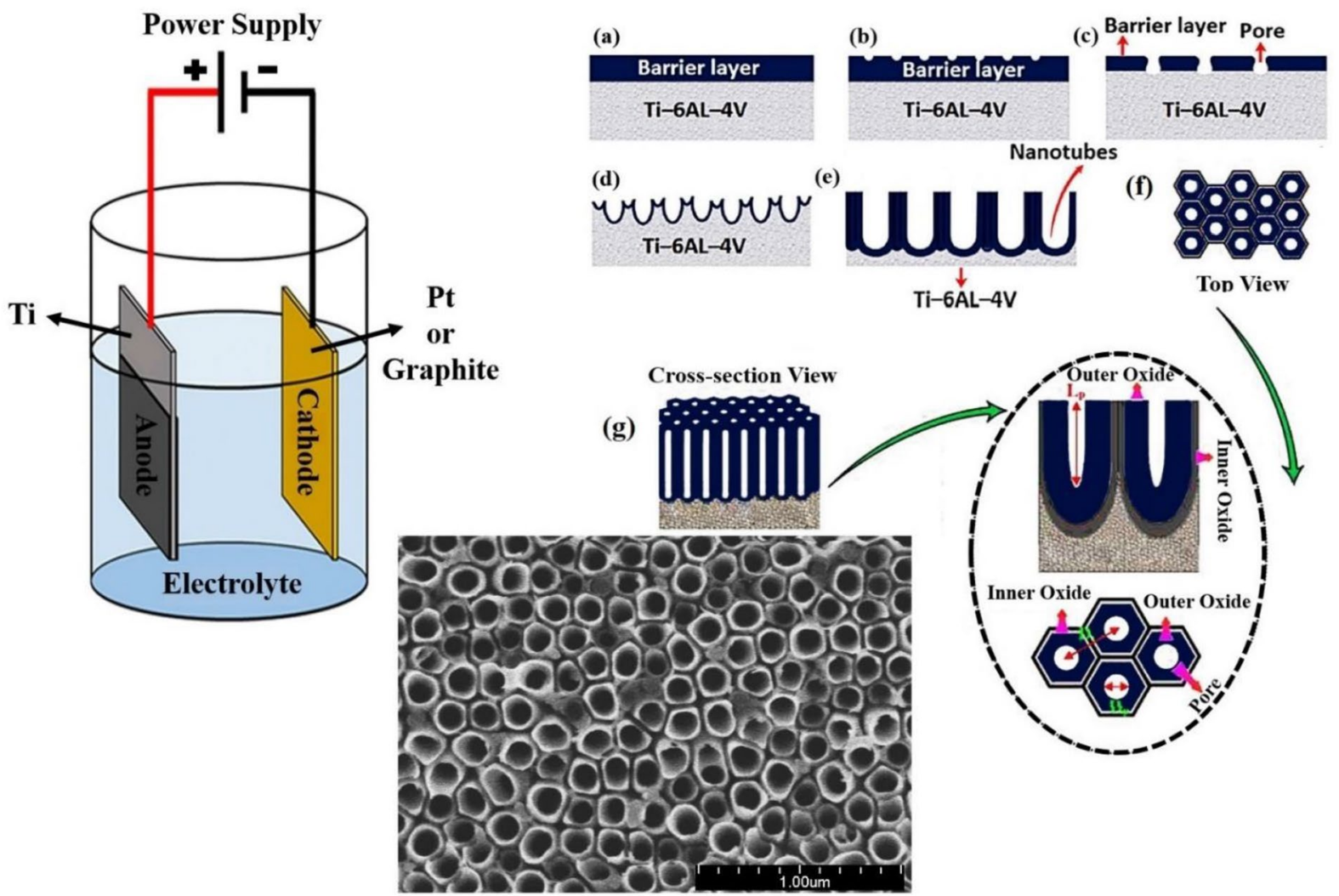

Fig. 4 Schematic of anodization process to fabricate titanium dioxide nanotube (TNT) arrays: a oxide layer formation, $\mathbf{b}$ pit creation, $\mathbf{c}$ pit growth, $\mathbf{d}$ oxidation and field-assisted dissolution of the metallic

is silver coating by PVD. Several researches have been conducted to develop antimicrobial coatings with titanium and silver using PVD [162, 163]. Some of the recent studies investigated the mixed system of anodization and PVD to improve the titanium/silver coating, and the results showed the deposition of $\mathrm{Ag}_{2} \mathrm{O}$ on the edges of highly ordered $\mathrm{TiO}_{2}$ nanotubular arrays (schematic shown in Fig. 5) [128].

Relevant techniques involve direct impregnation utilizing antibiotics before implantation, or polymer coatings doped with antibiotics or silver. The antimicrobial activity and non-toxic nature of active silver ions to human cells have been well established, as only a few bacteria are intrinsically resistant to silver via resistance mechanisms derived from plasmids $[162,164]$. The incorporation of silver ions into polymeric materials has been extensively performed for some time [165]. Urinary and central venous catheters use silver coatings, while dialysis units or heart valves have silver dotted surfaces to reduce infection [166]. Unfortunately, the relevant techniques may not meet the mechanical requirements for load-bearing biomedical implants, particularly those implanted into bone, due to the high levels of abrasive and shear forces occurring at the implant-bone interface. region between the pores, e fully developed nanotubular configurations with $\mathbf{f}$ a corresponding top view and $\mathbf{g}$ cross-sectional view with inner and outer oxides

Moreover, the PVD process is commonly utilized in medical and technical applications due to the excellent adhesiveness and wear resistance of ceramic and metallic coatings. In one study, silver-titanium was applied to samples of titanium alloys by PVD and tested for bactericidal action, biocompatibility, and hardness. The objective of the study was to assess the antimicrobial capability of coatings with silver ion under an aqueous environment, without compromising the hardness and biocompatibility of titanium with soft and hard tissue, for utilization in biomedical implants with load-bearing requirements, such as knee joints or hip joints [167].

In one study, both titanium and silver were vaporized in an atmosphere filled with inert argon, and antimicrobial coatings with a thickness of about $2 \mu \mathrm{m}$ were deposited on the titanium surface. Through X-ray analysis, the silver content of the coatings was determined to be about $0.7 \%$ to $9 \%$. Subsequently, eukaryotic culture cells and microorganisms were grown on these surfaces. After immersion in phosphate-buffered saline (PBS), the coatings released adequate amounts silver ions (between 0.5 and $2.3 \mathrm{ppb}$ ) and displayed remarkable antimicrobial potency against Klebsiella pneumoniae and Staphylococcus epidermidis strains. 


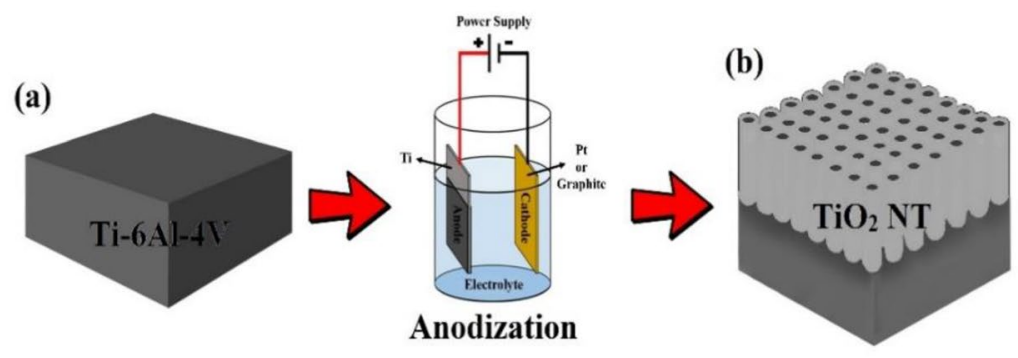

(c)
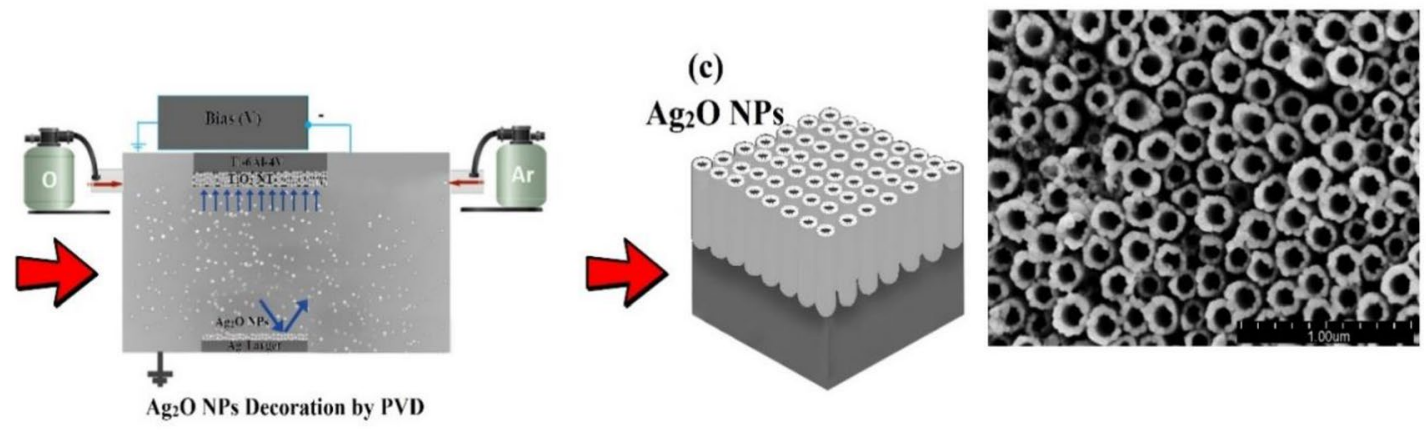

Fig. 5 a-c Schematic of a mixed system of anodization and PVD to deposit silver oxide on the edges of highly ordered $\mathrm{TiO}_{2}$ nanotubular arrays on Ti64

Furthermore, the coatings had no cytotoxic effects on the epithelial cells and osteoblasts [168].

Using commercial grade 2 pure titanium as control, the reaction of Klebsiella pneumoniae and Staphylococcus epidermidis bacterial strains on surfaces dotted with silver was observed. The datum for the adherence of bacteria to the control surface was defined as $100 \%$, and bacterial contamination on the surfaces containing silver was subsequently recorded. Klebsiella pneumoniae displayed reduced adhesion $(p<0.05)$ on the surfaces with $0.7 \%$ silver to $4 \%$ silver in the range of 32-64\%, respectively. Meanwhile, Staphylococcus epidermidis displayed reduced adhesion $(p<0.01)$ on the surfaces with $0.7-4 \%$ silver in the range of $43-52 \%$, respectively. Due to their similar mechanical performance to pure titanium, titanium silver (Ti-Ag) coatings may be a viable antimicrobial strategy for load-bearing implant surfaces [168].

\section{Advanced manufacturing (AM) of titanium alloys for biomedical application}

The fabrication techniques of titanium alloys for biomedical application include casting and powder metallurgy, cold working and hot working, machining, and additive manufacturing. Titanium alloys are manufactured into three types, including $\alpha, \beta$, and $\alpha+\beta$. Some alloying elements are dissolved preferentially in $\alpha$ phase such as $\mathrm{Zr}, \mathrm{Al}, \mathrm{Sn}, \mathrm{O}$, and Si raising the $\alpha+\beta$-phase. The addition of these elements results in the modification of alloy properties, such as in hardening and tensile strength improvement. Oxygen plays a dominant role controlling the range of strength of several grades, which are collectively called CP-Ti. The $\beta$-phase transformation stabilizes titanium alloys and makes them suitable for biomedical application because of their subsequent low modulus (which is below that of the $\alpha$ - and $\alpha+\beta$-phase and near that of the human femoral bone), and confers them high specific strength [76].

The CP-Ti and Ti-64 are manufactured via the traditional routes, such as strips, sheets, plates, bars, billets, forgings, and wires, specified according to the American Society for Testing and Materials (ASTM) as grades 1-5. Grades 1-4 comprise the unalloyed CP-Ti, and grade 5 is the alloyed Ti-64 [169]. One of the AM methods is the powder-based additive manufacturing technology of titanium and its alloys, with the advantages of low-cost, resource-saving, suitable time, and customized parameters for fabrication, and has received great attention for biomedical application [170]. The quality of additively manufactured implants highly depends on the selected additive manufacturing technique and the quality of titanium and its alloy powders. Additive manufacturing techniques employed to fabricate the biomaterials include directed energy deposition [171], laser-based powder bed fusion of metals (PBF-LB/M) [172], powder fed system of binder jetting [173], electron beam powder bed fusion of metals (PBF-EB/M) [174], plasma atomization [175], gas atomization [176], and plasma rotating electrode process [177].

Developments in porous titanium structures for biomaterial application have enabled design optimizations for 
patient-tailored implants. The additive manufacturing techniques allow for the fabrication of porous surface structures with predetermined, predictable unit cells for a biomedical implant, which have the necessary capabilities such as promoting cell proliferation and osseointegration. Thus, biomedical implants can achieve mechanical properties similar to those of human bone, such as compressive strength and elastic modulus, thereby preventing post-implantation complications, like stress shielding effects [178, 179]. To achieve such desired traits, it is necessary for biomedical implants to have an accurate design of porosities and pores to replicate the various mechanical properties and characteristics of the two main categories of bones, namely cortical bone and trabecular bone [180]. Despite having a similar composition, these two bone types vary in the degree of porosity and the proportion of organic and inorganic materials. The combination and organization of these two categories of bone differ according to the applied mechanical loading, as well as the skeletal region. Cell differentiation and proliferation are also affected by the morphology of pores, which is related to the pore size, porosity, and pore quantity [181].

Cellular structures can be classified into two main types, namely stochastic and non-stochastic. The cells in stochastic structures vary randomly in shape and size, while nonstochastic structures can be defined by the periodic repetition of the lattice structure with a unique shape and size of cells. Due to the absence of random variations in their cell shapes and sizes, non-stochastic metal structures are considered superior to stochastic metal foams on the basis of fabrication via powder bed technologies, which leads to better mechanical properties and the ease of removal of unfused powder [182, 183].

Evaluations have been performed on how variances in non-stochastic structures, such as the shape and size of pores, permeability, and porosity, affect the in vitro biological outcomes, as well as the mechanical properties of Ti-6Al-4V scaffolds fabricated via selective laser melting (SLM). The different pore shapes had an effect on cell permeability and consequently the number of cells attached to the Ti-6Al-4V scaffold. Other studies also reported that the circular cell growth pattern was not dependent on the shape and size of pore, which was primarily attributed to the amount of pore occlusion being higher on hexagonal pores in comparison to rectangular or triangular pores [184].

Moreover, research has been carried out on titanium hip implants with the aim of reducing the stress shielding effects without compromising mechanical strength. This was achieved by applying finite element analysis (FEA) to the design process and utilizing electron beam melting (EBM) fabrication technologies. A periodic lattice structure was used to modify the solid stems to achieve the desired reduction in implant stiffness. The comparisons between the constructed model and the simulated model demonstrated the possibility of utilizing EBM to fabricate non-stochastic lattice structures. The orientation of lattice struts was also instrumental to the fabrication process. Due to differences among the surfaces of struts between the EBM-fabricated model and the FEA-simulated model, the design of implants had to incorporate safety factors. The FEA model featured a consistent cross-section with a smooth surface, whereas the fabricated struts exhibited cross sections with slight variances coupled with textured surfaces. The study involved three model configurations, namely complete solid, hole configuration, and mesh configuration. The mesh configuration incorporated into the $\mathrm{Ti}-6 \mathrm{Al}-4 \mathrm{~V}$ stem was found to possess better stress distribution characteristics at the proximal portion of the femur [185-188].

Another study was conducted to determine the properties of porous structures in terms of internal geometry, pore size, and pore density in $\mathrm{Ti}-6 \mathrm{Al}-4 \mathrm{~V}$ fabricated by continuous laser melting deposition (LMD) and pulsed LMD. Both fabrication methods were shown to produce different internal porous structures, while optimizing the parameters such as laser power and powder mass flow rate yielded different densities in both cases. Ti-6Al-4V powder was used as the deposition material on the substrate, and parameter optimization resulted in the fabrication of suitable pores for osseointegration. Analytical models of the processes built by using Wolfram Mathematica software are also necessary to find interacting, transient heat, temperature, and mass flow models [189]. A more controlled porosity was obtainable by utilizing a pulsed beam fabrication methodology as compared to a continuous beam. A regular structure was instrumental to avoid premature failure [190].

\section{Effect of alloying elements on biocompatibility, corrosion resistance, and mechanical properties}

In order to develop safer biological Ti alloys with high strength and ductility, biocompatible alloying elements were examined as alternatives to $\mathrm{V}$ and $\mathrm{Al}$. The strength of the alloy was found to increase with the $\mathrm{Zr}$ and $\mathrm{Sn}$ content. In this regard, $\mathrm{Sn}$ is more effective than $\mathrm{Zr}$, while $\mathrm{Nb}$, $\mathrm{Ta}$, and $\mathrm{Pd}$ are less potent; therefore, the tensile strength of $\mathrm{Ti}-15 \mathrm{Sn}-4 \mathrm{Nb}-2 \mathrm{Ta}-0.2 \mathrm{Pd}$ is higher than that of Ti-6Al-4V for medial implants [191, 192]. Elements such as Mo, Zr, $\mathrm{Ta}, \mathrm{Sn}$, and $\mathrm{Nb}$ are selected as the safest alloying metals to adjust the properties of the biomaterial and maintain its suitability for implantation [76]. The $\beta$ alloying elements of titanium, including $\mathrm{V}, \mathrm{Mo}, \mathrm{Nb}, \mathrm{Ta}$, and $\mathrm{Zr}$, improve its corrosion behavior. Accordingly, it has been proven that Ti-6Al-4V has higher corrosion resistance compared to titanium alloyed with elements such as $\mathrm{Co}$ and $\mathrm{Cr}$ alloys, while pure titanium has higher pitting corrosion resistance rate. The $\beta$-phase stabilizing elements, such as Mo and V, 
improve the stress corrosion cracking of titanium owing to the increased heat treatment capability [193-195].

Titanium $\beta$-phase alloys, including $\mathrm{Ta}, \mathrm{Nb}, \mathrm{Zr}$, and $\mathrm{Sn}$, have excellent mechanical properties, such as low Young's modulus, high strength, good cold workability, and good biocompatibility and, therefore, have been more commonly used in recent years [76, 196, 197]. Moreover, Mo in titanium is not suitable for biomaterial application in high amounts due to the increased possibility of ion releasing to the surrounding tissue, resulting in totally diminished cytoplasm content and reduced cell spreading. Therefore, this element must be used in small quantities, just as $\mathrm{Ni}, \mathrm{V}$, and Al [198]. Cell culture experiments on osteoblast cells with $\mathrm{Ti}-5 \mathrm{Nb}-x \mathrm{Fe}$ alloys showed that the rate of cell proliferation is related to the amount of $\mathrm{Fe}$ and the chemical bonding between $\mathrm{Fe}$ and cells and that $\mathrm{Fe}$ with specific ratio has good biocompatibility [199]. The ranking of elements added to Ti in bioimplants regarding their cell viability enhancing effect, from lowest to highest, is $\mathrm{Cu}<\mathrm{Al}<\mathrm{Ag}<\mathrm{V}<\mathrm{Mn}<\mathrm{Cr}<\mathrm{Zr}$ $<\mathrm{Nb}<\mathrm{Mo}<\mathrm{Cp}$-Ti, and that regarding their cytotoxicity is $\mathrm{Cp}-\mathrm{Ti}<\mathrm{Sn}<\mathrm{Ta}<\mathrm{Mo}<\mathrm{Nb}<\mathrm{Zr}<\mathrm{Cr}<\mathrm{Mn}<\mathrm{V}<\mathrm{Ag}<\mathrm{Ni}=$ $\mathrm{Al}<\mathrm{Cu}$ [200-204].

\section{Potential of titanium alloys for regenerative medicine and nanomedicine}

\section{Properties of titania nanotube arrays (TNA)}

Nanomedicine aspires to supply a valuable set of research tools and clinically functional devices for different biomedical applications. Titania nanotube arrays (TNA), also known as titanium dioxide nanotube (TNT) arrays, are garnering significant prominence as nanomedicine technique thanks to improvements to orthopedic procedures due to its unique properties, including a high specific surface area and the capability to exhibit a positive cellular response. TNA can be fabricated by various chemical, electrochemical, and physical methods. Self-assembled nanotube arrays grown using anodic oxidation have been of particular interest due to the cost efficiency and ease of fabrication, combined with the exceptional electrical, optical, structural, and thermal properties exhibited by these nanotubes. The anodization layering process produces a continuous array of $\mathrm{TiO}_{2}$ nanotubes vertically aligned on the surface of titanium alloy [205-207].

\section{Applications in localized drug delivery systems}

$\mathrm{TiO}_{2}$ nanotubes (TNT) comprise a viable option for localized drug delivery systems to address shortfalls in conventional drug delivery. Several methodologies can be utilized to control extended drug release in small dosages for longterm therapies, such as adjustment of pore openings via biopolymer coatings, modification of internal chemical characteristics, regulation of TNT dimensions, and utilization of polymeric micelles as drug nanocarriers [208, 209]. Strategies to control drug delivery from TNTs are shown in Fig. 6. Emergency conditions, such as the sudden onset of inflammation, osteomyelitis, and unexpected viral attack, may arise with an imminent requirement for high concentrations of drugs [210]. Such critical situations can be addressed by employing stimuli-responsive drug delivery systems triggered by external conditions, such as magnetic, $\mathrm{pH}$, radiofrequency (RF), temperature, ultrasound, ultraviolet (UV) light, or voltage-sensitive drug delivery systems. The concept of stimuli release is based on the application of magnetic field, RF signal, ultrasonic wave, UV light, or voltage field to induce the movement of related stimuli particles, and forcing the release of polymer micelles out from the TNT. External stimuli for on-demand and responsive drug delivery can also be triggered via changes in the $\mathrm{pH}$ and temperature of the surrounding bioenvironment. The internal volume of TNT may be filled with biomolecules and chemicals, such as proteins or enzymes. Extrapolating this approach, titania nanotube arrays (TNA) may be coated with drugs that reduce inflammation, an example being dexamethasone, by utilizing the physical adsorption or deposition of a drug via a drug delivery system that is stimuli responsive. This application can work in conjunction with post-remission therapies, such as stem cell transplant and radiation therapy [211, 212].

Some researchers have attempted to fabricate smart implants with an on-off drug release capability using temperature as the external stimulus. It is assumed that the formation of a thermosensitive polymer coating on the surface of $\mathrm{TiO}_{2} \mathrm{NTs}$ endows a sustained release potential, resulting in lower required drug dosages and decreased systemic toxicity. The schematic of the drug encapsulation and release mechanisms is shown in Fig. 7. The polymer coating on top of the nanotubes undergoes a rapid transition from a hydrophilic state with coil-shaped polymer chains to hydrophobic globules at a specific temperature, which results in the release of the drugs in a specific area of the human body. This phenomenon leads to the partial removal of the protective shell from the surface of $\mathrm{TiO}_{2} \mathrm{NTs}$ and the generation of preferred trajectories for drug diffusion within the surrounding environment [213, 214].

\section{Applications as immunomodulatory agents}

Recent advancements in nanomedicine have facilitated the development of new immunomodulatory agents that include immunosuppressive agents or immunologically active components. In conjunction with an immunosuppressive agent, the unique surface structure of TNA enables the effective reduction of compromising immune responses that would contribute to unsuccessful transplants as a result of 

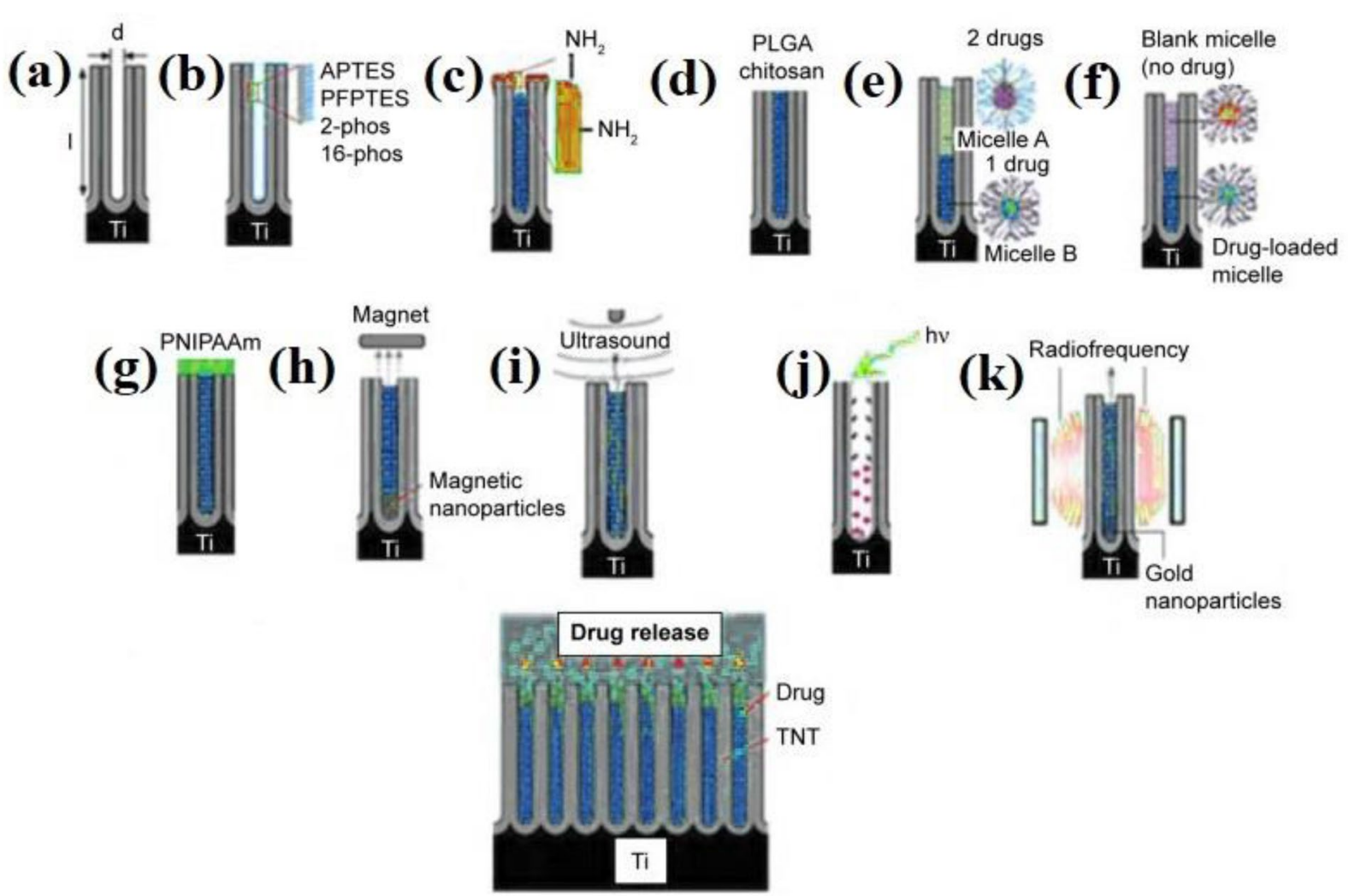

Fig. 6 Strategies for controlling drug release from TNTs. a Controlling the diameter and length of nanotubes; $\mathbf{b}$ surface chemistry (hydrophobic, hydrophilic, charged); c tuning the nanotube opening by plasma polymerization; $\mathbf{d}$ degradation of dip-coated polymer film closing the nanotubes (PLGA or chitosan); e using drug nanocarriers

localized autoimmune or allergic reactions [205, 215]. Such applications have the potential to significantly enhance clinical outcomes for a range of infectious and non-infectious diseases.

\section{Applications as antibacterial agents}

Coating the TNA nanomatrix surface with drugs that reduce infections, including streptomycin and penicillin, can be utilized to mitigate the bacterial colonization of indwelling medical devices. The medical device surface is aligned with TNA to act as an antimicrobial chemotherapy agent. The internal cylindrical surface of the aligned TNA is then coated with bactericidal antibiotics such as streptomycin and penicillin. This antibacterial surface provided by the TNA coated with bactericidal antibiotics has proved to inhibit and mitigate bacterial growth, thereby reducing the risk of bacterial infection originating from the system [216, 217]. Nanomedicine approaches also provide an enhanced solution to limit bacterial infection by delivering traditional antibiotic treatments. Research has established the utilization of nanotubes with larger diameters (30 to (micelles) for multidrug delivery; $\mathbf{f}$ delayed/sequential drug release of drugs/drug carriers. External field-triggered drug release using $\mathbf{g}$ temperature, $\mathbf{h}$ magnetic field, $\mathbf{i}$ ultrasound, $\mathbf{j}$ light, and $\mathbf{k}$ radiofrequency with gold nanoparticles. Only a single nanotube structure is shown to present an array of TNTs

$100 \mathrm{~nm})$ as compared to nanotubes with smaller diameters (around $20 \mathrm{~nm}$ ), which may potentially stunt the growth of bacteria such as Staphylococcus epidermidis or Staphylococcus aureus [218].

\section{Applications for hemocompatibility}

TNA is a viable option as a nano-blood-contacting agent; it has the ability to transform fibrinogen to fibrin, thereby increasing the formation of a dense fibrin network and subsequently reducing the clotting time. The topology of TNA is conducive to enhancing the activation and adhesion of platelets, protein absorption of the blood serum, and kinetics of blood coagulation. In addition, the surface of TNA has the potential to act as a link between biological substances for propitious implants that are blood related [219]. TNA also evokes low cytokine secretion and monocyte activation. The adsorption of blood on TNA enables further evaluation through the utilization of micro bicinchoninic acid (BCA) assay, as well as X-ray photoelectron spectroscopy [220-222]. 
(a)

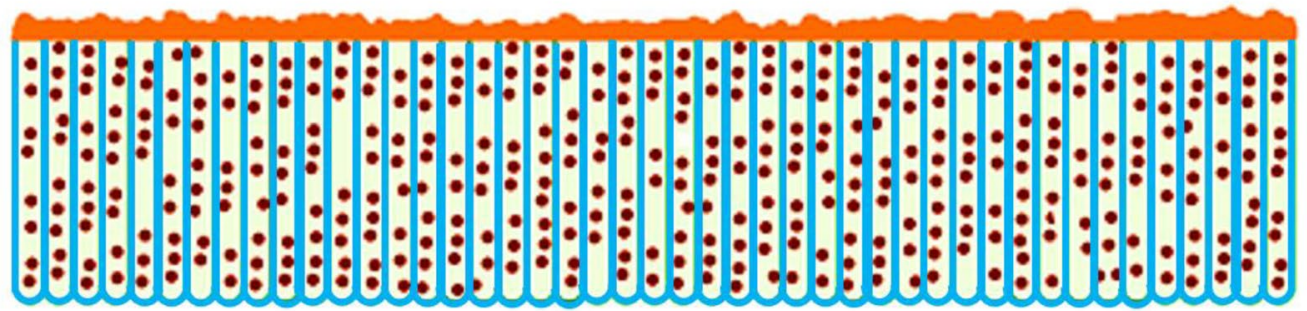

(b)

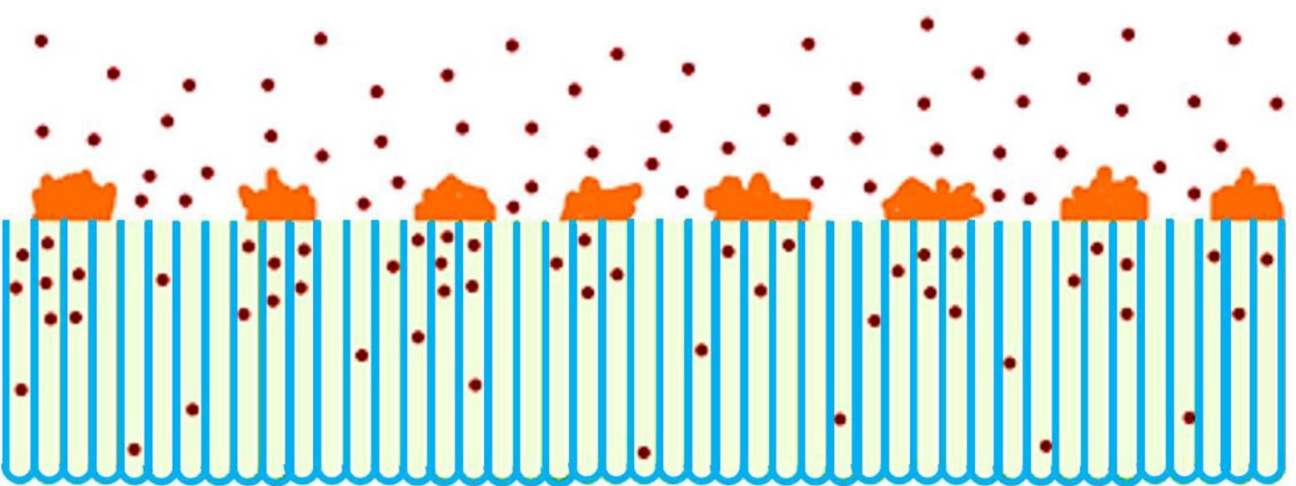

Nanotubes

Drug

Polymer Capping

Fig. 7 Proposed mechanism of thermal-triggered drug release from polymer-coated $\mathrm{TiO}_{2}$ nanotubular structures before $\mathbf{a}$ and after $\mathbf{b}$ heating. At low temperatures, the polymer capping forms a uniform protective layer on the nanotubes, resulting in a negligible level of

\section{Conclusions and future directions}

Pure titanium (Ti) and its alloys have been used extensively as medical implants owing to their high biocompatibility, fatigue life, corrosion resistance, and lower Young's modulus compared to other medical implants. With the development of AM technologies over recent years, the fabrication of medical devices has not only become cheaper and faster in comparison with conventional manufacturing techniques, but also these products have demonstrated superior mechanical properties with reduced tooling operations and material wastage. The biomedical application of AM technologies has garnered considerable popularity in recent years due to improved capabilities in the fabrication of implants specifically tailored to individual patients. AM technologies using biomaterials such as titanium can replicate patient organs and tissues with precision, which allows for the reproduction of complex porous structures that enable tailored cell morphologies, promote cell differentiation and proliferation, a requirement for bone in-growth, and act as an antimicrobial agent. These benefits consequently reduce the risk of implant rejection and accelerate the healing process. uncontrolled drug release. However, heating of the implant to a specific temperature leads to the coil-to-globule transition of the polymer shell and the provision of preferred routes for drug diffusion

Ongoing research is being conducted on orthopedic devices constructed from porous metal. Based on clinical studies using such porous metals like titanium foam, the formation of vascular systems in a porous area seems viable. The mechanisms of osseointegration in titanium foams share similarities with that in bone grafts, whereby the porous properties of the titanium foam facilitate considerable bone infiltration, allowing osteoblast activity to occur. Furthermore, the porous structure enhances vascularization and the adherence of soft tissue within the implant. Therefore, the utility of porous materials may see a future expansion in replacement arthroplasty and dental applications.

In the nanotechnology field, biomedical research and development primarily target improvements to current diagnostic and therapeutic methodologies. The ultimate goal is to reduce the overall medical cost by improving the efficiency and reusability of available practices. Thus far, titanium nanostructures have proved to be a viable option for advanced biomedical implants, as well as theragnostic applications; however, a more in-depth understanding of the biomolecular interactions involving titanium as a nanomaterial is necessary for further developments in this field. 
Acknowledgements The authors would like to acknowledge the National University of Singapore, Sharif University of Technology, and University of Malaya for providing necessary resources and facilities for this study. This project was supported by the University of Malaya (UM) Research Grant: (FRGS/1/2020/TK0/UM/02/40).

Author contributions MS was involved in conceptualization, investigation, validation, writing — original draft, writing—review and editing, and visualization. ERG was involved in conceptualization, validation, writing - original draft, and writing-review and editing. SA was involved in conceptualization, investigation, writing-original draft, and visualization. SR was involved in writing-review and editing and supervision. NLS was involved in writing-review and editing and supervision.

\section{Declarations}

Conflict of interest The authors declare that they have no conflict of interest.

Ethical approval This study does not contain any studies with human or animal subjects performed by any of the authors.

\section{References}

1. Goncalves AD, Balestri W, Reinwald Y (2020) Biomedical implants for regenerative therapies. Biomaterials. https://doi. org/10.5772/intechopen.91295

2. Kurtz S, Ong K, Lau E et al (2007) Projections of primary and revision hip and knee arthroplasty in the United States from 2005 to 2030. J Bone Joint Surg Am 89(4):780-785. https://doi.org/ 10.2106/JBJS.F.00222

3. Khosravi F, Khorasani SN, Khalili S et al (2020) Development of a highly proliferated bilayer coating on $316 \mathrm{~L}$ stainless steel implants. Polymers 12(5):1022. https://doi.org/10.3390/polym 12051022

4. Santos G (2017) The importance of metallic materials as biomaterials. Adv Tissue Eng Regen Med Open Access 3(1):300-302

5. Sarraf M, Zalnezhad E, Bushroa AR et al (2014) Structural and mechanical characterization of $\mathrm{Al} / \mathrm{Al}_{2} \mathrm{O}_{3}$ nanotube thin film on TiV alloy. Appl Surface Sci 321:511-519. https://doi.org/10. 1016/j.apsusc.2014.10.040

6. Xu WC, Yu F, Yang LH et al (2018) Accelerated corrosion of 316L stainless steel in simulated body fluids in the presence of $\mathrm{H}_{2} \mathrm{O}_{2}$ and albumin. Mater Sci Eng C 92:11-19. https://doi.org/ 10.1016/j.msec.2018.06.023

7. Yamanaka K, Mori M, Kartika I et al (2019) Effect of multipass thermomechanical processing on the corrosion behaviour of biomedical Co-Cr-Mo alloys. Corrosion Sci 148:178-187. https:// doi.org/10.1016/j.corsci.2018.12.009

8. Biesiekierski A, Munir K, Li YC et al (2020) Material selection for medical devices. Metallic Biomater Process Med Dev Manuf 2020:31-94. https://doi.org/10.1016/B978-0-08-1029657.00002-3

9. Su EP, Justin DF, Pratt CR et al (2018) Effects of titanium nanotubes on the osseointegration, cell differentiation, mineralisation and antibacterial properties of orthopaedic implant surfaces. Bone Joint J 100-B(1 Supple A):9-16. https://doi.org/10.1302/ 0301-620X.100B1.BJJ-2017-0551.R1

10. Kopova I, Kronek J, Bacakova L et al (2019) A cytotoxicity and wear analysis of trapeziometacarpal total joint replacement implant consisting of DLC-coated Co-Cr-Mo alloy with the use of titanium gradient interlayer. Diamond Related Mater 97:107456. https://doi.org/10.1016/j.diamond.2019.107456

11. Bothe R (1940) Reaction of bone to multiple metallic implants. Surg Gynecol Obstet 71:598-602

12. Kroll W (1940) The production of ductile titanium. Trans Electrochem Soc 78(1):35. https://doi.org/10.1149/1.3071290

13. Leventhal GS (1951) Titanium, a metal for surgery. J Bone Joint Surg Am 33(2):473-474. https://doi.org/10.2106/00004 623-195133020-00021

14. Beder OE, Stevenson JK, Jones TW (1957) A further investigation of the surgical application of titanium metal in dogs. Surgery 41(6):1012-1015 (PMID: 13442870)

15. Martola M, Lindqvist C, Hänninen $\mathrm{H}$ et al (2007) Fracture of titanium plates used for mandibular reconstruction following ablative tumor surgery. J Biomed Mater Res B Appl Biomater 80(2):345-352. https://doi.org/10.1002/jbm.b.30603

16. Van Noort R (1987) Titanium: the implant material of today. J Mater Sci 22(11):3801-3811. https://doi.org/10.1007/BF011 33326

17. Venkatesh B, Chen D, Bhole S (2008) Three-dimensional fractal analysis of fracture surfaces in a titanium alloy for biomedical applications. Scripta Mater 59(4):391-394. https://doi.org/ 10.1016/j.scriptamat.2008.04.010

18. Ran J, Jiang FC, Sun XJ et al (2020) Microstructure and mechanical properties of Ti-6Al-4V fabricated by electron beam melting. Curr Comput-Aided Drug Des 10(11):972. https://doi.org/10.3390/cryst10110972

19. Fu Y, Xiao WL, Wang JS et al (2021) A novel strategy for developing $\alpha+\beta$ dual-phase titanium alloys with low Young's modulus and high yield strength. J Mater Sci Technol 76:122128. https://doi.org/10.1016/j.jmst.2020.11.018

20. Semlitsch MF, Weber H, Streicher RM et al (1992) Joint replacement components made of hot-forged and surfacetreated Ti-6Al-7Nb alloy. Biomaterials 13(11):781-788. https://doi.org/10.1016/0142-9612(92)90018-J

21. Whittenberger JD, Moore TJ (1979) Elevated temperature flow strength, creep resistance and diffusion welding characteristics of Ti-6Al-2Nb-1Ta-0.8 Mo. Metallurgical Trans A 10(11):1597-1605. https://doi.org/10.1007/BF02811691

22. Hanawa T (2012) Research and development of metals for medical devices based on clinical needs. Sci Technol Adv Mater 13(6):064102. https://doi.org/10.1088/1468-6996/13/6/064102

23. Maehara K, Doi K, Matsushita T et al (2002) Application of vanadium-free titanium alloys to artificial hip joints. Mater Trans 43(12):2936-2942. https://doi.org/10.2320/matertrans. 43.2936

24. Aguilar C, Arancibia M, López LA et al (2019) Influence of porosity on the elastic modulus of Ti-Zr-Ta-Nb foams with a low $\mathrm{Nb}$ content. Metals 9(2):176. https://doi.org/10.3390/met90 20176

25. Wang KK, Gustavson LJ, Dumbleton JH (1996). Microstructure and properties of a new beta titanium alloy, Ti-12Mo-6Zr$2 \mathrm{Fe}$, developed for surgical implants. In: Brown SA, Lemons JE (Eds.), Medical Applications of Titanium and Its Alloys: the Material and Biological Issues, American Sociery for Testing and Materials, USA, p. 76-87. https://doi.org/10.1520/STP16 $071 \mathrm{~S}$

26. Im YD, Lee YK (2020) Effects of Mo concentration on recrystallization texture, deformation mechanism and mechanical properties of Ti-Mo binary alloys. J Alloys Compd 821:153508. https:// doi.org/10.1016/j.jallcom.2019.153508

27. Pellizzari M, Jam A, Tachon M et al (2020) A 3D-printed ultralow Young's modulus $\beta$-Ti alloy for biomedical applications. Materials 13(12):2792. https://doi.org/10.3390/ma13122792

28. Koizumi H, Ishii T, Okazaki T et al (2018) Castability and mechanical properties of $\mathrm{Ti}-15 \mathrm{Mo}-5 \mathrm{Zr}-3 \mathrm{Al}$ alloy in dental 
casting. J Oral Sci 60(2):285-292. https://doi.org/10.2334/ josnusd.17-0280

29. Okazaki Y (2001) A new Ti-15Zr-4Nb-4Ta alloy for medical applications. Curr Opin Solid State Mater Sci 5(1):45-53. https://doi.org/10.1016/S1359-0286(00)00025-5

30. Matsuda Y, Nakamura T, Ido M et al (1997) Femoral component made of Ti-15Mo-5Zr-3Al alloy in total hip arthroplasty. J Orthop Sci 2(3):166-170. https://doi.org/10.1007/BF02492973

31. Bruschi M, Steinmüller-Nethl D, Goriwoda W et al (2015) Composition and modifications of dental implant surfaces. J Oral Implants 2015:527426. https://doi.org/10.1155/2015/ 527426

32. Ida K, Togaya T, Tsutsumi $\mathrm{S}$ et al (1982) Effect of magnesia investments in the dental casting of pure titanium or titanium alloys. Dent Mater J 1(1):8-21. https://doi.org/10.4012/dmj.1.8

33. Marteleur M, Sun F, Gloriant T et al (2012) On the design of new $\beta$-metastable titanium alloys with improved work hardening rate thanks to simultaneous TRIP and TWIP effects. Scripta Mater 66(10):749-752. https://doi.org/10.1016/j.scriptamat.2012.01. 049

34. Buehler WJ, Gilfrich JV, Wiley R (1963) Effect of low-temperature phase changes on the mechanical properties of alloys near composition TiNi. J Appl Phys 34(5):1475-1477. https://doi.org/ 10.1063/1.1729603

35. Luo Y, Yang L, Tian M (2013) Application of biomedical-grade titanium alloys in trabecular bone and artificial joints. In: Davim P (Ed.), Biomaterials and Medical Tribology. Woodhead Publishing, Elsevier, p. 181-216. https://doi.org/10.1533/9780857092 205.181

36. Xue L, Koul AK, Bibby M et al (1970) A survey of surface treatments to improve the fretting fatigue resistance of Ti-6Al-4V. WIT Trans Eng Sci 8:265-272. https://doi.org/10.2495/SURF9 50311

37. Hanawa T (2019) Overview of metals and applications. In Niinomi M (Ed.), Metals for Biomedical Devices, Woodhead Publishing, p.3-24. https://doi.org/10.1533/9781845699246.1.3

38. Semlitsch M, Staub F, Weber H (1985) Titanium-aluminiumniobium alloy, development for biocompatible, high strength surgical implants - Titan-Aluminium-NIOB-Legierung, entwickelt für körperverträgliche, hochfeste implantate in der chirurgie. Biomed Eng Biomed Technik 30(12):334-339. https://doi.org/ 10.1515/bmte.1985.30.12.334

39. Bhambri SK, Shetty RH, Gilbertson LN (1996) Optimization of properties of Ti-15Mo-2.8Nb-3Al-0.2Si \& Ti-15Mo-2.8Nb$0.2 \mathrm{Si}-.260$ beta titanium alloys for application in prosthetic implants. In: Brown SA, Lemons JE (Eds.), Medical Applications of Titanium and Its Alloys: the Material and Biological Issues. American Sociery for Testing and Materials, USA, p. 88-95

40. Niinomi M (1998) Mechanical properties of biomedical titanium alloys. Mater Sci Eng A 243(1-2):231-236. https://doi.org/10. 1016/S0921-5093(97)00806-X

41. Elias L, Schneider SG, Schneider S et al (2006) Microstructural and mechanical characterization of biomedical $\mathrm{Ti}-\mathrm{Nb}-\mathrm{Zr}(-\mathrm{Ta})$ alloys. Mater Sci Eng A 432(1-2):108-112. https://doi.org/10. 1016/j.msea.2006.06.013

42. Hao Y, Yang R, Niinomi M et al (2003) Aging response of the Young's modulus and mechanical properties of Ti-29Nb-13Ta-46 $\mathrm{Zr}$ for biomedical applications. Metallurgical Mater Trans A 34(4):1007-1012. https://doi.org/10.1007/s11661-003-0230-x

43. Xu L, Chen YY, Liu ZG et al (2008) The microstructure and properties of $\mathrm{Ti}-\mathrm{Mo}-\mathrm{Nb}$ alloys for biomedical application. $\mathrm{J}$ Alloys Compd 453(1-2):320-324. https://doi.org/10.1016/j.jallc om.2006.11.144

44. Yang R, Hao Y, Li S (2011) Development and application of lowmodulus biomedical titanium alloy Ti2448. Biomed Eng Trends 10:225-247. https://doi.org/10.5772/13269
45. Warburton A, Girdler SJ, Mikhail CM et al (2020) Biomaterials in spinal implants: a review. Neurospine 17(1):101. https://doi. org/10.14245/ns.1938296.148

46. Tan JH, Cheong CK, Hey HWD (2021) Titanium (Ti) cages may be superior to polyetheretherketone (PEEK) cages in lumbar interbody fusion: a systematic review and meta-analysis of clinical and radiological outcomes of spinal interbody fusions using Ti versus PEEK cages. Europ Spine J 30(5):1285-1295. https://doi.org/10.1007/s00586-021-06748-w

47. Alvarez AG, Evans PL, Dovgalski L et al (2021) Design, additive manufacture and clinical application of a patient-specific titanium implant to anatomically reconstruct a large chest wall defect. Rapid Prototyping J 27(2):1355-2546

48. Baltatu MS, Tugui CA, Perju MC, et al (2019). Biocompatible titanium alloys used in medical applications. Rev Chim 70(4):1302-1306. https://doi.org/10.37358/RC.19.4.7114

49. Vijayavenkataraman S, Gopinath A, Lu WF (2020) A new design of 3D-printed orthopedic bone plates with auxetic structures to mitigate stress shielding and improve intra-operative bending. Bio-Des Manuf 3:98-108. https://doi.org/10.1007/ s42242-020-00066-8

50. Shakir DA, Abdul-Ameer FM (2018) Effect of nano-titanium oxide addition on some mechanical properties of silicone elastomers for maxillofacial prostheses. J Taibah Univ Med Sci 13(3):281-290. https://doi.org/10.1016/j.jtumed.2018.02.007

51. Cevik P, Eraslan O (2017) Effects of the addition of titanium dioxide and silaned silica nanoparticles on the mechanical properties of maxillofacial silicones. J Prosthodontics C 26(7):611615. https://doi.org/10.1111/jopr.12438

52. Asserghine A, Filotás D, Németh B et al (2018) Potentiometric scanning electrochemical microscopy for monitoring the $\mathrm{pH}$ distribution during the self-healing of passive titanium dioxide layer on titanium dental root implant exposed to physiological buffered (PBS) medium. Electrochem Commun 95:1-4. https:// doi.org/10.1016/j.elecom.2018.08.008

53. Das R, Bhattacharjee C (2019). Titanium-based nanocomposite materials for dental implant systems. In Asiri AM, Inamuddin, Mohammad A (Eds.), Applications of Nanocomposite Materials in Dentistry, Woodhead Publishing, p.271-284. https://doi.org/ 10.1016/B978-0-12-813742-0.00016-X

54. Niinomi M (2003) Recent research and development in titanium alloys for biomedical applications and healthcare goods. Sci Technol Adv Mater 4(5):445. https://doi.org/10.1016/j.stam. 2003.09.002

55. Herrmann H, Kern JS, Kern T et al (2020) Early and mature biofilm on four different dental implant materials: an in vivo human study. Clin Oral Implants Res 31(11):1094-1104. https://doi.org/ 10.1111/clr.13656

56. Wu C, Wang Q, Mao T et al (2019) Relationship between lattice defects and phase transformation in hydrogenation/dehydrogenation process of the $\mathrm{V}_{60} \mathrm{Ti}_{25} \mathrm{Cr}_{3} \mathrm{Fe}_{12}$ alloy. Int $\mathrm{J}$ Hydrogen Energy 44(18):9368-9377. https://doi.org/10.1016/j.ijhydene.2019.02. 097

57. Shahryari L, JavidSharifi B, Dabaghmanesh M (2019) A case study of performance improvement of femur prosthesis. J Struct Eng Geo-Techn 10(2):57-75

58. Kumari N, Kumar K (2017). Mechanisms and materials of orthotic calipers for polio infected patients-a review. Proc 2nd International Conference for Convergence in Technology (I2CT), p.7-9. https://doi.org/10.1109/I2CT.2017.8226086

59. Zhu Y, Liu DD, Wang XL et al (2019) Polydopamine-mediated covalent functionalization of collagen on a titanium alloy to promote biocompatibility with soft tissues. J Mater Chem B 7(12):2019-2031. https://doi.org/10.1039/c8tb03379j

60. Hol MK, Cremers CWRJ, Coppens-Schellekens W et al (2005) The BAHA softband: a new treatment for young children with 
bilateral congenital aural atresia. Int J Pediatr Otorhinolaryngol 69(7):973-980. https://doi.org/10.1016/j.ijporl.2005.02.010

61. Ferreira CC, Ricci VP, Sousa LL et al (2017) Improvement of titanium corrosion resistance by coating with poly-caprolactone and poly-caprolactone/titanium dioxide: potential application in heart valves. Mater Res 20:126-133. https://doi.org/10. 1590/1980-5373-MR-2017-0425

62. Aikawa Y, Kataoka Y, Kanaya T et al (2018) Procedural challenge of coronary catheterization for ST-segment elevation myocardial infarction in patient who underwent transcatheter aortic valve replacement using the CoreValveTM. Cardiovasc Diagn Ther 8(2):190-195. https://doi.org/10.21037/cdt.2018. 04.02

63. King MW, Bambharoliya T, Ramakrishna H et al (2020) Evolution of angioplasty devices. In Coronary Artery Disease and the Evolution of Angioplasty Devices, Springer, New York

64. Meininghaus DG, Kruells-Muench J, Peltroche-Llacsahuanga $H$ (2020) First-in-man implantation of a gold-coated biventricular defibrillator: difficult differential diagnosis of metal hypersensitivity reaction vs chronic device infection. HeartRhythm Case Rep 6(6):304-307. https://doi.org/10.1016/j.hrcr.2020.02.004

65. Kashin OA, Krukovskii KV, Lotkov AI (2018). Opportunities and prospects for the use of porous silicon to create a polymer-free drug coating on intravascular stents. AIP Conf Proc 2051(1):020119-020119-4.

66. Suzuki T, Tokuda Y, Kobayashi H (2017) The development of yellow nail syndrome after the implantation of a permanent cardiac pacemaker. Intern Med 56(19):2667-2669. https://doi.org/ 10.2169/internalmedicine.8769-16

67. Olin C (2001) Titanium in cardiac and cardiovascular applications. In: Brunette DM, Tengvall P, Textor M et al (Eds.), Titanium in Medicine, Springer, p.889-907. https://doi.org/10.1007/ 978-3-642-56486-4_26

68. Martov AG, Plekhanova OA, Ergakov DV et al (2020) Thermoexpandable urethral nickel-titanium stent memokath for managing urethral bulbar stricture after failed urethroplasty. J Endourol Case Rep 6(3):147-149. https://doi.org/10.1089/cren.2019.0146

69. Froes F, Qian M (2018) Titanium in medical and dental applications. Woodhead Publishing

70. Froes FS (2018). Titanium for medical and dental applications - an introduction. In Froes FH, Qian M (Eds.), Titanium in Medical and Dental Applications, Woodhead Publishing, p.3-21. https://doi.org/10.1016/B978-0-12-812456-7.00001-9

71. Abecassis IJ, Sen RD, Ellenbogen RG et al (2021) Developing microsurgical milestones for psychomotor skills in neurological surgery residents as an adjunct to operative training: the home microsurgery laboratory. J Neurosurg 135(1):318-326. https:// doi.org/10.3171/2020.5.JNS201590

72. Glenn CA, Baker CM, Burks JD et al (2018) Dural closure in confined spaces of the skull base with nonpenetrating titanium clips. Operative Neurosurg 14(4):375-385. https://doi.org/10. 1093/ons/opx140

73. Gunawarman B, Niinomi M, Akahori T et al (2005) Mechanical properties and microstructures of low cost $\beta$ titanium alloys for healthcare applications. Mater Sci Eng C 25(3):304-311. https:// doi.org/10.1016/j.msec.2004.12.015

74. Hong SH, Hwang YJ, Park SW et al (2019) Low-cost beta titanium cast alloys with good tensile properties developed with addition of commercial material. J Alloys Compd 793:271-276. https://doi.org/10.1016/j.jallcom.2019.04.200

75. Abdalla AO, Amrin A, Muhammad S et al (2017) Iron as a promising alloying element for the cost reduction of titanium alloys: a review. Appl Mech Mater 864:147-153. https://doi.org/10.4028/ www.scientific.net/AMM.864.147

76. Khorasani AM, Goldberg M, Doeven EH et al (2015) Titanium in biomedical applications-properties and fabrication: a review. J Biomater Tissue Eng 5(8):593-619. https://doi.org/ 10.1166/jbt.2015.1361

77. Stepanovskaa J, Matejka R, Rosina J et al (2019) Treatments for enhancing the biocompatibility of titanium implants: a review. Biomed Pap Med Fac Univ Palacky Olomouc Czech Repub 164(1):23-33. https://doi.org/10.5507/bp.2019.062

78. Khodaei M, Kelishadi SH (2018) The effect of different oxidizing ions on hydrogen peroxide treatment of titanium dental implant. Surface Coatings Technol 353:158-162. https://doi. org/10.1016/j.surfcoat.2018.08.037

79. Huang J, Chen HZ, Pan W et al (2020) Effect of nitrogen on the microstructures and mechanical behavior of Ti-6Al-4V alloy additively manufactured via tungsten inert gas welding. Mater Today Commun 24:101171. https://doi.org/10.1016/j.mtcomm. 2020.101171

80. Baig MN, Khan FN, Junaid M (2007) Comparison of microstructure, mechanical properties, and residual stresses in tungsten inert gas, laser, and electron beam welding of Ti-5 Al-2.5 Sn titanium alloy. Proc Inst Mech Eng Part L J Mater Des Appl 233(7):1336-1351

81. Paranthaman V, Dhinakaran V, Swapna Sai M et al (2021) A systematic review of fatigue behaviour of laser welding titanium alloys. Mater Today Proc 39(1):520-523. https://doi.org/ 10.1016/j.matpr.2020.08.249

82. Kumar SR, Kulkarni SK (2017) Analysis of hard machining of titanium alloy by Taguchi method. Mater Today Proc 4(10):10729-10738. https://doi.org/10.1016/j.matpr.2017.08. 020

83. Sadeghpour S, Abbasi SM, Morakabati M et al (2018) A new multi-element beta titanium alloy with a high yield strength exhibiting transformation and twinning induced plasticity effects. Scripta Mater 145:104-108. https://doi.org/10.1016/j. scriptamat.2017.10.017

84. Hao X, Dong HG, Xia YQ et al (2019) Microstructure and mechanical properties of laser welded TC4 titanium alloy/304 stainless steel joint with $(\mathrm{CoCrFeNi})_{100-x} \mathrm{Cu}_{x}$ high-entropy alloy interlayer. J Alloys Compd 803:649-657. https://doi.org/ 10.1016/j.jallcom.2019.06.225

85. Al-Murshdy JMS, Ghayyib BJ (2019) Effect of heat treatment on properties of titanium biomedical alloy. J Univ Babylon Eng Sci 27(1):232-246

86. Koizumi H, Takeuchi Y, Imai H et al (2019) Application of titanium and titanium alloys to fixed dental prostheses. J Prosthodont Res 63(3):266-270. https://doi.org/10.1016/j.jpor. 2019.04.011

87. Łęcka K, Gąsiorek J, Mazur-Nowacka A et al (2019) Adhesion and corrosion resistance of laser-oxidized titanium in potential biomedical application. Surface Coatings Technol 366:179-189. https://doi.org/10.1016/j.surfcoat.2019.03.032

88. Sarraf M, Sukiman NL, Nasiri-Tabrizi B et al (2019) In vitro bioactivity and corrosion resistance enhancement of Ti-6Al-4V by highly ordered $\mathrm{TiO}_{2}$ nanotube arrays. J Aust Ceramic Soc 55(1):187-200. https://doi.org/10.1007/s41779-018-0224-1

89. Cora ÖN, Koç M (2019) Micromanufacturing. Mod Manuf Process 7:149-184. https://doi.org/10.1002/9781119120384.ch7

90. Verma RP (2020) Titanium based biomaterial for bone implants: a mini review. Mater Today Proc 26:3148-3151. https://doi.org/ 10.1016/j.matpr.2020.02.649

91. Rafieerad A, Bushroa AR, Zalnezhad E et al (2015) Microstructural development and corrosion behavior of self-organized $\mathrm{TiO}_{2}$ nanotubes coated on Ti-6Al-7Nb. Ceramics Int 41(9):1084410855. https://doi.org/10.1016/j.ceramint.2015.05.025

92. Gong D, Wang HL, Obbard EG et al (2020) Tuning thermal expansion by a continuing atomic rearrangement mechanism in a multifunctional titanium alloy. J Mater Sci Technol 80:234-243. https://doi.org/10.1016/j.jmst.2020.11.053 
93. Heary RF, Parvathreddy N, Sampath S et al (2017). Elastic modulus in the selection of interbody implants. J Spine Surg 3(2):163-167. https://doi.org/10.21037/jss.2017.05.01

94. Suzuki G, Hirota M, Hoshi N (2019) Effect of surface treatment of multi-directionally forged (MDF) titanium implant on bone response. Metals 9(2):230. https://doi.org/10.3390/met90 20230

95. Fousova M, Vojtech D, Jablonska E et al (2017) Novel approach in the use of plasma spray: preparation of bulk titanium for bone augmentations. Materials 10(9):987. https://doi.org/10.3390/ ma10090987

96. Kholgh Eshkalak S, Rezvani Ghomi E, Dai YQ et al (2020) The role of three-dimensional printing in healthcare and medicine. Mater Des 194:108940. https://doi.org/10.1016/j.matdes.2020. 108940

97. Niinomi M, Liu Y, Nakai M et al (2016) Biomedical titanium alloys with Young's moduli close to that of cortical bone. Regenerative biomaterials 3(3):173-185. https://doi.org/10.1093/rb/ rbw016

98. O'Brien T, Weisman DS, Ronchetti P et al (2004) Flexible titanium nailing for the treatment of the unstable pediatric tibial fracture. J Pediatr Orthop 24(6):601-609. https://doi.org/10. 1097/00004694-200411000-00001

99. Niinomi M, Nakai M, Hieda J (2012) Development of new metallic alloys for biomedical applications. Acta Biomater 8(11):3888-3903. https://doi.org/10.1016/j.actbio.2012.06.037

100. Niinomi M (2011) Low modulus titanium alloys for inhibiting bone atrophy. Biomater Sci Eng. https://doi.org/10.5772/24549

101. Kondoh K, Umeda J, Soba R, et al (2018). Advanced TiNi shape memory alloy stents fabricated by a powder metallurgy route. In Froes FH, Qian M (Eds.), Titanium in Medical and Dental Applications, Woodhead Publishing, p.583-590. https://doi.org/ 10.1016/B978-0-12-812456-7.00027-5

102. Plaine AH, da Silva MR, Bolfarini C (2019). Microstructure and elastic deformation behavior of $\beta$-type Ti-29Nb-13Ta-4.6Zr with promising mechanical properties for stent applications. J Mater Res Technol 8(5):3852-3858. https://doi.org/10.1016/j.jmrt. 2019.06.047

103. Li P, Ma XD, Tong T et al (2019) Microstructural and mechanical properties of $\beta$-type Ti-Nb-Sn biomedical alloys with low elastic modulus. Metals 9(6):712. https://doi.org/10.1016/j.jallc om.2019.152412

104. Kim HY, Ohmatsu Y, Kim JI et al (2004) Mechanical properties and shape memory behavior of Ti-Mo-Ga alloys. Mater Trans 45(4):1090-1095. https://doi.org/10.2320/matertrans.45.1090

105. Miyazaki S, Kim HY, Hosoda H (2006) Development and characterization of Ni-free Ti-base shape memory and superelastic alloys. Mater Sci Eng A 438:18-24. https://doi.org/10.1016/j. msea.2006.02.054

106. Shinohara Y, Matsumoto Y, Tahara M et al (2018) Development of $<001\rangle$-fiber texture in cold-groove-rolled Ti-Mo-Al-Zr biomedical alloy. Materialia 1:52-61. https://doi.org/10.1016/j.mtla. 2018.07.008

107. Maeshima T, Nishida M (2004) Shape memory and mechanical properties of biomedical Ti-Sc-Mo alloys. Mater Trans 45(4):1101-1105. https://doi.org/10.2320/MATERTRANS.45. 1101

108. Li B, Xie R, Lu X (2020) Microstructure, mechanical property and corrosion behavior of porous $\mathrm{Ti}-\mathrm{Ta}-\mathrm{Nb}-\mathrm{Zr}$. Bioactive Mater 5(3):564-568. https://doi.org/10.1016/j.bioactmat.2020.04.014

109. Dorozhkin SV (2017) Calcium orthophosphate coatings and other deposits. Front Nanobiomed Res 3:1-84. https://doi.org/ 10.1186/2194-0517-1-1

110. Gallinetti S, Kihlstrom Burenstam Linder L, Åberg J et al (2021) Titanium reinforced calcium phosphate improves bone formation and osteointegration in ovine calvaria defects: a comparative 52-weeks study. Biomed Mater 16(3):035031. https://doi.org/10.1088/1748-605X/abca12

111. Domínguez-Trujillo C, Peón E, Chicardi E et al (2018) Sol-gel deposition of hydroxyapatite coatings on porous titanium for biomedical applications. Surface Coatings Technol 333:158162. https://doi.org/10.1016/j.surfcoat.2017.10.079

112. Hu C, Aindow M, Wei M (2017) Focused ion beam sectioning studies of biomimetic hydroxyapatite coatings on Ti-6Al-4V substrates. Surface Coatings Technol 313:255-262. https://doi. org/10.1016/j.surfcoat.2017.01.103

113. Ke D, Vu AA, Bandyopadhyay A (2019) Compositionally graded doped hydroxyapatite coating on titanium using laser and plasma spray deposition for bone implants. Acta Biomater 84:414-423. https://doi.org/10.1016/j.actbio.2018.11.041

114. Cao J, Lian R, Jiang XH (2020) Magnesium and fluoride doped hydroxyapatite coatings grown by pulsed laser deposition for promoting titanium implant cytocompatibility. Appl Surface Sci 515:146069. https://doi.org/10.1016/j.apsusc.2020.146069

115. Ambrogio G, Palumbo G, Sgambitterra E et al (2018) Experimental investigation of the mechanical performances of titanium cranial prostheses manufactured by super plastic forming and single-point incremental forming. Int J Adv Manuf Technol 98(5):1489-1503. https://doi.org/10.1007/s00170-018-2338-6

116. Alagarsamy K, Vishwakarma V, Kaliaraj GS (2019) Synthesis and characterization of bioactive composite coating on titanium by PVD for biomedical application. IOP Conf Ser Mater Sci Eng 561:012027. https://doi.org/10.1088/1757-899X/ $561 / 1 / 012027$

117. Won S, Huh YH, Cho LR et al (2017) Cellular response of human bone marrow derived mesenchymal stem cells to titanium surfaces implanted with calcium and magnesium ions. Tissue Eng Regener Med 14(2):123-131. https://doi.org/10. 1007/s13770-017-0028-3

118. Karimi N, Kharaziha M, Raeissi K (2019) Electrophoretic deposition of chitosan reinforced graphene oxide-hydroxyapatite on the anodized titanium to improve biological and electrochemical characteristics. Mater Sci Eng C 98:140-152. https:// doi.org/10.1016/j.msec.2018.12.136

119. Lu M, Chen H, Yuan B et al (2020) Electrochemical deposition of nanostructured hydroxyapatite coating on titanium with enhanced early stage osteogenic activity and osseointegration. Int J Nanomed 15:6605-6618. https://doi.org/10.2147/IJN. S268372

120. Kokubo T, Yamaguchi S (2016) Novel bioactive materials developed by simulated body fluid evaluation: surface-modified ti metal and its alloys. Acta Biomater 44:16-30. https://doi.org/ 10.1016/j.actbio.2016.08.013

121. Hanawa T (2019) Titanium-tissue interface reaction and its control with surface treatment. Front Bioeng Biotechnol 7:170. https://doi.org/10.3389/fbioe.2019.00170

122. Surender L, Rekha RK, Veerendra NRP et al (2011) Surface characteristics of titanium dental implants for rapid osseointegration. Indian J Dent Adv 3(3):602-612

123. Le Guéhennec L, Soueidan A, Layrolle P et al (2007) Surface treatments of titanium dental implants for rapid osseointegration. Dent mater 23(7):844-854. https://doi.org/10.1016/j.dental.2006. 06.025

124. Yu M, Gong JX, Zhou Y et al (2017) Surface hydroxyl groups regulate the osteogenic differentiation of mesenchymal stem cells on titanium and tantalum metals. J Mater Chem B 5(21):39553963. https://doi.org/10.1039/c7tb00111h

125. Paradowska E, Arkusz K, Pijanowska DG (2019) The influence of the parameters of a gold nanoparticle deposition method on titanium dioxide nanotubes, their electrochemical response, and protein adsorption. Biosensors 9(4):138. https://doi.org/10.3390/ bios 9040138 
126. Jia E, Zhao X, Lin Y et al (2020) Protein adsorption on titanium substrates and its effects on platelet adhesion. Appl Surface Sci 529:146986. https://doi.org/10.1016/j.apsusc.2020.146986

127. Hiji A, Hanawa T, Shimabukuro M et al (2021) Initial formation kinetics of calcium phosphate on titanium in Hanks' solution characterized using XPS. Surface Interf Anal 53(2):185-193. https://doi.org/10.1002/sia.6900

128. Sarraf M, Dabbagh A, Abdul Razak B et al (2018) Highlyordered $\mathrm{TiO}_{2}$ nanotubes decorated with $\mathrm{Ag}_{2} \mathrm{O}$ nanoparticles for improved biofunctionality of Ti6A14V. Surface Coatings Technol 349:1008-1017. https://doi.org/10.1016/j.surfcoat.2018.06.054

129. Souza JC, Sordi MB, Kanazawa M et al (2019) Nano-scale modification of titanium implant surfaces to enhance osseointegration. Acta Biomater 94:112-131. https://doi.org/10.1016/j.actbio. 2019.05.045

130. Rezvani Ghomi E, Eshkalak Saeideh K, Singh S et al (2021) Fused filament printing of specialized biomedical devices: a state-of-the art review of technological feasibilities with PEEK. Rapid Prototyping J 27(3):592-616. https://doi.org/10.1108/ rpj-06-2020-0139

131. Stacchi C, Barlone L, Rapani A et al (2020) Modified orthodontic bone stretching for ankylosed tooth repositioning: a case report. Open Dent J 14(1):235-239. https://doi.org/10.2174/1874210602 014010235

132. Wang C, Wang SN, Yang YY et al (2018) Bioinspired, biocompatible and peptide-decorated silk fibroin coatings for enhanced osteogenesis of bioinert implant. J Biomater Sci Polymer Ed 29(13):1595-1611. https://doi.org/10.1080/09205063.2018. 1477316

133. Romanov DA, Sosnin KV, Filyakov AD et al (2021) The effect of bioinert electroexplosive coatings on stress distribution near the dental implant-bone interface. Mater Res Expr 8(1):015016. https://doi.org/10.1088/2053-1591/abd664

134. Siddiqi A, Payne AGT, De Silva RK et al (2011) Titanium allergy: could it affect dental implant integration? Clin Oral Implants Res 22(7):673-680. https://doi.org/10.1111/j.16000501.2010.02081.x

135. Wang X, Lu L, Feng Y et al (2019) Macrophage polarization in aseptic bone resorption around dental implants induced by Ti particles in a murine model. J Periodont Res 54(4):329-338. https://doi.org/10.1111/jre.12633

136. Civantos A, Domínguez C, Pino RJ et al (2019) Designing bioactive porous titanium interfaces to balance mechanical properties and in vitro cells behavior towards increased osseointegration. Surface Coatings Technol 368:162-174. https://doi.org/10. 1016/j.surfcoat.2019.03.001

137. Wang Q, Zhou P, Liu SF et al (2020) Multi-scale surface treatments of titanium implants for rapid osseointegration: a review. Nanomaterials 10(6):1244. https://doi.org/10.3390/nano100612 44

138. Taniyama T, Saruta J, Rezaei NM et al (2020) UV-photofunctionalization of titanium promotes mechanical anchorage in a rat osteoporosis model. Int J Mol Sci 21(4):1235. https://doi.org/10. 3390/ijms21041235

139. Zhang H, Komasa S, Mashimo C et al (2017) Effect of ultraviolet treatment on bacterial attachment and osteogenic activity to alkali-treated titanium with nanonetwork structures. Int J Nanomed 12:4633. https://doi.org/10.2147/IJN.S136273

140. Itabashi T, Narita K, Ono A et al (2017) Bactericidal and antimicrobial effects of pure titanium and titanium alloy treated with short-term, low-energy UV irradiation. Bone Joint Res 6(2):108112. https://doi.org/10.1302/2046-3758.62.2000619

141. Javadhesari SM, Alipour S, Akbarpour M (2020) Biocompatibility, osseointegration, antibacterial and mechanical properties of nanocrystalline Ti-Cu alloy as a new orthopedic material. Colloids Surfaces B Biointerf 189:110889
142. Bono N, Ponti F, Punta C et al (2021) Effect of UV irradiation and $\mathrm{TiO}_{2}$-photocatalysis on airborne bacteria and viruses: an overview. Materials 14(5):1075. https://doi.org/10.3390/ma140 51075

143. Guo C, Wang $\mathrm{K}$, Hou $\mathrm{S}$ et al (2017) $\mathrm{H}_{2} \mathrm{O}_{2}$ and/or $\mathrm{TiO}_{2}$ photocatalysis under UV irradiation for the removal of antibiotic resistant bacteria and their antibiotic resistance genes. J Hazardous Mater 323:710-718. https://doi.org/10.1016/j.jhazmat.2016.10.041

144. Chouirfa H, Bouloussa H, Migonney V et al (2019) Review of titanium surface modification techniques and coatings for antibacterial applications. Acta Biomater 83:37-54. https://doi.org/ 10.1016/j.actbio.2018.10.036

145. Sarraf M, Dabbagh A, Razak BA et al (2018) Silver oxide nanoparticles-decorated tantala nanotubes for enhanced antibacterial activity and osseointegration of Ti6A14V. Mater Des 154:28-40. https://doi.org/10.1016/j.matdes.2018.05.025

146. Wang Y, Zhang MJ, Li KM et al (2021) Study on the surface properties and biocompatibility of nanosecond laser patterned titanium alloy. Optics Laser Technol 139:106987. https://doi.org/ 10.1016/j.optlastec.2021.106987

147. Taherian M, Rezazadeh M, Taji A (2021) Optimum surface roughness for titanium-coated PEEK produced by electron beam PVD for orthopedic applications. Mater Technol. https://doi.org/ 10.1080/10667857.2020.1868209

148. Hwang YJ, Choi YS, Hwang YH et al (2021) Biocompatibility and biological corrosion resistance of $\mathrm{Ti}-39 \mathrm{Nb}-6 \mathrm{Zr}+045 \mathrm{Al}$ implant alloy. J Funct Biomater 12(1):2. https://doi.org/10.3390/ jfb12010002

149. Fathyunes L, Khalil-Allaf J, Moosavifa M (2019) Development of graphene oxide/calcium phosphate coating by pulse electrodeposition on anodized titanium: biocorrosion and mechanical behavior. J Mech Behav Biomed Mater 90:575-586. https://doi. org/10.1016/j.jmbbm.2018.11.011

150. Vogel D, Dempwolf H, Baumann A et al (2017) Characterization of thick titanium plasma spray coatings on PEEK materials used for medical implants and the influence on the mechanical properties. J Mech Behav Biomed Mater B 77:600-608. https:// doi.org/10.1016/j.jmbbm.2017.09.027

151. Lukaszewska-Kuska M, Wirstlein P, Majchrowski R et al (2018) Osteoblastic cell behaviour on modified titanium surfaces. Micron 105:55-63. https://doi.org/10.1016/j.micron.2017.11.010

152. Guillem-Marti J, Boix Lemonche G, Gugutkov D et al (2018) Recombinant fibronectin fragment III8-10/polylactic acid hybrid nanofibers enhance the bioactivity of titanium surface. Nanomedicine 13(8):899-912. https://doi.org/10.2217/nnm-2017-0342

153. Sarraf M, Razak BA, Nasiri-Tabrizi B et al (2017) Nanomechanical properties, wear resistance and in-vitro characterization of $\mathrm{Ta}_{2} \mathrm{O}_{5}$ nanotubes coating on biomedical grade Ti-6Al-4V. J Mech Behav Biomed Mater 66:159-171. https://doi.org/10. 1016/j.jmbbm.2016.11.012

154. Zhou L, Pan M, Zhang ZH et al (2021) Enhancing osseointegration of TC4 alloy by surficial activation through biomineralization method. Front Bioeng Biotechnol 9:120. https://doi.org/10. 3389/fbioe.2021.639835

155. Sarraf M, Razak A, Crum R et al (2017) Adhesion measurement of highly-ordered $\mathrm{TiO}_{2}$ nanotubes on Ti-6Al-4V alloy. Proc Appl Ceramics 11(4):311-321. https://doi.org/10.2298/PAC1704311S

156. Sarraf M, Zalnezhad E, Bushroa AR et al (2015) Effect of microstructural evolution on wettability and tribological behavior of $\mathrm{TiO}_{2}$ nanotubular arrays coated on Ti-6Al-4V. Ceramics Int 41(6):7952-7962. https://doi.org/10.1016/j.ceramint.2015.02. 136

157. Praharaj R, Mishra S, Rautray TR (2020) The structural and bioactive behaviour of strontium-doped titanium dioxide nanorods. J Korean Ceramic Soc 57(3):271-280. https://doi.org/10.1007/ s43207-020-00027-y 
158. Zalnezhad E, Maleki E, Banihashemian SM et al (2016) Wettability, structural and optical properties investigation of $\mathrm{TiO}_{2}$ nanotubular arrays. Mater Res Bull 78:179-185. https://doi.org/ 10.1016/j.materresbull.2016.01.035

159. Kunrath MF, Vargas ALM, Sesterheim P et al (2020) Extension of hydrophilicity stability by reactive plasma treatment and wet storage on $\mathrm{TiO}_{2}$ nanotube surfaces for biomedical implant applications. J Royal Soc Interf 17(170):20200650. https://doi.org/10. 1098/rsif.2020.0650

160. Sarraf M, Razak BA, Dabbagh A et al (2016) Optimizing PVD conditions for electrochemical anodization growth of welladherent $\mathrm{Ta}_{2} \mathrm{O}_{5}$ nanotubes on Ti-6Al-4V alloy. RSC Adv 6(82):78999-79015. https://doi.org/10.1039/C6RA11290K

161. Cui C, Liu H, Li YC et al (2015) Fabrication and biocompatibility of nano- $\mathrm{TiO}_{2} /$ titanium alloys biomaterials. Mater Lett 59(24-25):3144-3148. https://doi.org/10.1016/j.matlet.2005. 05.037

162. Smeets R, Precht $C$, Hahn $M$ et al (2017) Biocompatibility and osseointegration of titanium implants with a silver-doped polysiloxane coating: an in vivo pig model. Int J Oral Maxillofac Implants 32(6):1338-1345. https://doi.org/10.11607/jomi.5533

163. Rashid S, Sebastiani M, Zeeshan Mughal M et al (2021) Influence of the silver content on mechanical properties of Ti-Cu-Ag thin films. Nanomaterials 11(2):435. https://doi.org/10.3390/ nano11020435

164. Bui VD, Mwangi JW, Meinshausen AK et al (2020) Antibacterial coating of Ti-6Al-4V surfaces using silver nano-powder mixed electrical discharge machining. Surface Coatings Technol 383:125254. https://doi.org/10.1016/j.surfcoat.2019.125254

165. Gaviria J, Alcudia A, Begines B et al (2021) Synthesis and deposition of silver nanoparticles on porous titanium substrates for biomedical applications. Surface Coatings Technol 406:126667. https://doi.org/10.1016/j.surfcoat.2020.126667

166. Mandakhalikar KD, Wang R, Rahmat JN et al (2018) Restriction of in vivo infection by antifouling coating on urinary catheter with controllable and sustained silver release: a proof of concept study. BMC Infect Dis 18(1):1-9. https://doi.org/10.1186/ s12879-018-3296-1

167. Kheur S, Singh N, Bodas D et al (2017) Nanoscale silver depositions inhibit microbial colonization and improve biocompatibility of titanium abutments. Colloids Surf B Biointerf 159:151-158. https://doi.org/10.1016/j.colsurfb.2017.07.079

168. Ewald A, Glückermann SK, Thull R et al (2006) Antimicrobial titanium/silver PVD coatings on titanium. Biomed Eng Online 5(1):1-10. https://doi.org/10.1186/1475-925X-5-22

169. Sidambe AT (2014) Biocompatibility of advanced manufactured titanium implants-a review. Mater 7(12):8168-8188. https:// doi.org/10.3390/ma7128168

170. Jang TS, Kim DE, Han G et al (2020) Powder based additive manufacturing for biomedical application of titanium and its alloys: a review. Biomed Eng Lett 10(4):505-516. https://doi. org/10.1007/s13534-020-00177-2

171. Chen Y, Clark S, Sinclair L et al (2021) Synchrotron X-ray imaging of directed energy deposition additive manufacturing of titanium alloy Ti-6242. Addit Manuf 41:101969. https://doi.org/10. 1016/j.addma.2021.101969

172. Dong Y, Li YL, Zhou SY et al (2021) Cost-affordable Ti-6Al-4V for additive manufacturing: powder modification, compositional modulation and laser in-situ alloying. Addit Manuf 37:101699. https://doi.org/10.1016/j.addma.2020.101699

173. Barthel B, Janas F, Wieland S (2021) Powder condition and spreading parameter impact on green and sintered density in metal binder jetting. Powder Metall. https://doi.org/10.1080/ 00325899.2021 .1912923

174. Bieske J, Franke M, Schloffer M et al (2020) Microstructure and properties of TiAl processed via an electron beam powder bed fusion capsule technology. Intermetallics 126:106929. https:// doi.org/10.1016/j.intermet.2020.106929

175. Kalayda T, Kirsankin A, Ivannikov AY et al (2021) The plasma atomization process for the Ti-Al-V powder production. J Phys Conf Ser 1942:012046

176. Perminov A, Bartzsch G, Franke A et al (2021) Manufacturing Fe-TiC Composite powder via inert gas atomization by forming reinforcement phase in situ. Adv Eng Mater 23(3):2000717. https://doi.org/10.1002/adem.202000717

177. Nie Y, Tang JJ, Ye XJ et al (2020) Particle defects and related properties of metallic powders produced by plasma rotating electrode process. Adv Powder Technol 31(7):2912-2920. https:// doi.org/10.1016/j.apt.2020.05.018

178. Taniguchi N, Fujibayashi S, Takemoto M et al (2016) Effect of pore size on bone ingrowth into porous titanium implants fabricated by additive manufacturing: an in vivo experiment. Mater Sci Eng C Mater Biol Appl 59:690-701. https://doi.org/10. 1016/j.msec.2015.10.069

179. Wang X, Xu SQ, Zhou SW et al (2016) Topological design and additive manufacturing of porous metals for bone scaffolds and orthopaedic implants: a review. Biomaterials 83:127-141. https://doi.org/10.1016/j.biomaterials.2016.01.012

180. Ragone V, Canciani E, Arosio M et al (2020) In vivo osseointegration of a randomized trabecular titanium structure obtained by an additive manufacturing technique. J Mater Sci Mater Med 31(2):1-11. https://doi.org/10.1007/s10856-019-6357-0

181. Barba D, Alabort E, Reed R (2019) Synthetic bone: design by additive manufacturing. Acta Biomater 97:637-656. https://doi. org/10.1016/j.actbio.2019.07.049

182. Egan DS, Dowling DP (2019) Influence of process parameters on the correlation between in-situ process monitoring data and the mechanical properties of Ti-6Al-4V non-stochastic cellular structures. Addit Manuf 30:100890. https://doi.org/10.1016/j. addma.2019.100890

183. Trevisan F, Calignano F, Aversa A et al (2018) Additive manufacturing of titanium alloys in the biomedical field: processes, properties and applications. J Appl Biomater Funct Mater 16(2):57-67. https://doi.org/10.5301/jabfm.5000371

184. Dhiman S, Sidhu SS, Singh P et al (2019) Mechanobiological assessment of Ti-6Al-4V fabricated via selective laser melting technique: a review. Rapid Prototyping J 25:1266-1284. https:// doi.org/10.1108/RPJ-03-2019-0057

185. Ameen W, Al-Ahmari A, Mohammed MK et al (2018) Design, finite element analysis (FEA), and fabrication of custom titanium alloy cranial implant using electron beam melting additive manufacturing. Advn Prod Eng Manage 13(3):267-278. https:// doi.org/10.14743/apem2018.3.289

186. He Y, Burkhalter D, Durocher D et al (2018). Solid-lattice hip prosthesis design: applying topology and lattice optimization to reduce stress shielding from hip implants. 2018 Design of Medical Devices Conference p.9-12. https://doi.org/10.1115/DMD20 $18-6804$

187. Murr L (2017) Open-cellular metal implant design and fabrication for biomechanical compatibility with bone using electron beam melting. J Mech Behav Biomed Mater 76:164-177. https:// doi.org/10.1016/j.jmbbm.2017.02.019

188. Weißmann V, Drescher P, Bader R et al (2017) Comparison of single Ti6Al4V struts made using selective laser melting and electron beam melting subject to part orientation. Metals 7(3):91. https://doi.org/10.3390/MET7030091

189. Soylemez E (2020) High deposition rate approach of selective laser melting through defocused single bead experiments and thermal finite element analysis for Ti-6Al-4V. Addit Manuf 31:100984. https://doi.org/10.1016/j.addma.2019.100984

190. Grabovetskaya GP, Stepanova EN, Mishin IP et al (2020) The effect of irradiation of a titanium alloy of the Ti-6Al-4V-H 
system with pulsed electron beams on its creep. Russian Phys $\mathbf{J}$ 63(6):932-939. https://doi.org/10.1007/s11182-020-02120-5

191. Adamovic D, Ristic B, Zivic F (2018). Review of existing biomaterials - method of material selection for specific applications in orthopedics. In: Zivic F, Affatato S, Trajanovic M (Eds.), Biomaterials in Clinical Practice, Springer, Cham, p.47-99. https:// doi.org/10.1007/978-3-319-68025-5_3

192. Wang J, Li QQ, Xiong CY et al (2018) Effect of Zr on the martensitic transformation and the shape memory effect in Ti-Zr-NbTa high-temperature shape memory alloys. J Alloys Compounds 737:672-677. https://doi.org/10.1016/j.jallcom.2017.12.003

193. Cui YW, Chen LY, Liu XX (2021) Pitting corrosion of biomedical titanium and titanium alloys: a brief review. Curr Nanosci 17(2):241-256. https://doi.org/10.2174/15734137169992011252 21211

194. Chui P, Jing R, Zhang FG et al (2020) Mechanical properties and corrosion behavior of $\beta$-type Ti-Zr-Nb-Mo alloys for biomedical application. J Alloys Compounds 842:155693. https://doi.org/10. 1016/j.jallcom.2020.155693

195. Tardelli JDC, Bolfarini C, Dos Reis AC (2020) Comparative analysis of corrosion resistance between beta titanium and Ti-6Al-4V alloys: a systematic review. J Trace Elements Med Biol 62:126618. https://doi.org/10.1016/j.jtemb.2020.126618

196. Konopatsky A, Dubinskiy SM, Zhukova YS et al (2017) Ternary $\mathrm{Ti}-\mathrm{Zr}-\mathrm{Nb}$ and quaternary Ti-Zr-Nb-Ta shape memory alloys for biomedical applications: structural features and cyclic mechanical properties. Mater Sci Eng A 702:301-311. https://doi.org/10. 1016/j.msea.2017.07.046

197. Wei K, Wang Z, Zeng X (2018) Effect of heat treatment on microstructure and mechanical properties of the selective laser melting processed Ti-5Al-2.5 Sn $\alpha$ titanium alloy. Mater Sci Eng A 709:301-311. https://doi.org/10.1016/j.msea.2017.10.061

198. Eisenbarth E, Velten D, Müller M et al (2004) Biocompatibility of $\beta$-stabilizing elements of titanium alloys. Biomaterials 25(26):5705-5713. https://doi.org/10.1016/j.biomaterials.2004. 01.021

199. Hsu HC, Hsu SK, Wu SC et al (2010) Structure and mechanical properties of as-cast $\mathrm{Ti}-5 \mathrm{Nb}-x \mathrm{Fe}$ alloys. Mater Charact 61(9):851-858. https://doi.org/10.1016/j.matchar.2010.05.003

200. Chen S, Tsoi JKH, Tsang PCS et al (2020) Candida albicans aspects of binary titanium alloys for biomedical applications. Regener Biomater 7(2):213-220. https://doi.org/10.1093/rb/rbz052

201. Iijima Y, Nagase T, Matsugaki A et al (2021) Design and development of $\mathrm{Ti}-\mathrm{Zr}-\mathrm{Hf}-\mathrm{Nb}-\mathrm{Ta}-\mathrm{Mo}$ high-entropy alloys for metallic biomaterials. Mater Des 202:109548. https://doi.org/10.1016/j. matdes.2021.109548

202. Nagase T, Iijima Y, Matsugaki A et al (2020) Design and fabrication of Ti-Zr-Hf-Cr-Mo and Ti-Zr-Hf-Co-Cr-Mo high-entropy alloys as metallic biomaterials. Mater Sci Eng C 107:110322. https://doi.org/10.1016/j.msec.2019.110322

203. Park YJ, Song YH, An JH et al (2013) Cytocompatibility of pure metals and experimental binary titanium alloys for implant materials. J Dent 41(12):1251-1258. https://doi.org/10.1016/j. jdent.2013.09.003

204. Cremasco A, Messias AD, Esposito AR et al (2011) Effects of alloying elements on the cytotoxic response of titanium alloys. Mater Sci Eng C 31(5):833-839. https://doi.org/10.1016/j.msec. 2010.12.013

205. Mydin R, Hazan R, FaridWajidi AF et al (2018). Titanium dioxide nanotube arrays for biomedical implant materials and nanomedicine applications. In Yang DF (Ed.), Titanium DioxideMaterial for a Sustainable Environment, p.469-483. https://doi. org/10.5772/intechopen.73060

206. Kafshgari MH, Goldmann WH (2020) Insights into theranostic properties of titanium dioxide for nanomedicine. Nano-Micro Lett 12(1):1-35. https://doi.org/10.1007/s40820-019-0362-1
207. Sarraf M, Nasiri-Tabrizi B, Yeong CH et al (2020) Mixed oxide nanotubes in nanomedicine: a dead-end or a bridge to the future? Ceram Int 47(3):2917-2948. https://doi.org/10.1016/j.ceramint. 2020.09.177

208. Kunrath MF, Hubler R, Shinkai R et al (2018) Application of $\mathrm{TiO}_{2}$ nanotubes as a drug delivery system for biomedical implants: a critical overview. Chem Select 3(40):11180-11189. https://doi.org/10.1002/slct.201801459

209. Dabbagh A, Hedayatnasab Z, Karimian H et al (2019) Polyethylene glycol-coated porous magnetic nanoparticles for targeted delivery of chemotherapeutics under magnetic hyperthermia condition. Int J Hyperthermia 36(1):104-114. https://doi.org/ $10.1080 / 02656736.2018 .1536809$

210. Nancy D, Rajendran N (2018) Vancomycin incorporated chitosan/gelatin coatings coupled with $\mathrm{TiO}_{2}-\mathrm{SrHAP}$ surface modified cp-titanium for osteomyelitis treatment. Int J Biol Macromol 110:197-205. https://doi.org/10.1016/j.ijbiomac.2018.01. 004

211. Wang Q, Huang JY, Li HQ et al (2017) Recent advances on smart $\mathrm{TiO}_{2}$ nanotube platforms for sustainable drug delivery applications. Int J Nanomed 12:151-165. https://doi.org/10.2147/IJN. S117498

212. Wang Q, Huang JY, Li HQ et al (2016) $\mathrm{TiO}_{2}$ nanotube platforms for smart drug delivery: a review. Int J Nanomed 11:4819-4834. https://doi.org/10.2147/IJN.S108847

213. Jia H, Kerr LL (2015) Kinetics of drug release from drug carrier of polymer/ $/ \mathrm{TiO}_{2}$ nanotubes composite- $\mathrm{pH}$ dependent study. J Appl Polymer Sci 132(7):41570. https://doi.org/10.1002/APP. 41570

214. Wang T, Weng ZY, Liu XM et al (2017) Controlled release and biocompatibility of polymer/titania nanotube array system on titanium implants. Bioactive Mater 2(1):44-50. https://doi.org/ 10.1016/j.bioactmat.2017.02.001

215. Ma A, You YP, Chen B et al (2020) Icariin/aspirin composite coating on $\mathrm{TiO}_{2}$ nanotubes surface induce immunomodulatory effect of macrophage and improve osteoblast activity. Coatings 10(4):427. https://doi.org/10.3390/coatings 10040427

216. Zhang X, Zhang Y, Yates MZ (2018) Hydroxyapatite nanocrystal deposited titanium dioxide nanotubes loaded with antibiotics for combining biocompatibility and antibacterial properties. MRS Adv 3(30):1703-1709. https://doi.org/10.1557/adv.2018.114

217. Mesbah M, Sarraf M, Dabbagh A et al (2020) Synergistic enhancement of photocatalytic antibacterial effects in highstrength aluminum $/ \mathrm{TiO}_{2}$ nanoarchitectures. Ceramics Int 46(15):24267-24280. https://doi.org/10.1016/j.ceramint.2020. 06.207

218. Sm RB, Sreekantan S, Hazan R et al (2017) Cellular homeostasis and antioxidant response in epithelial HT29 cells on titania nanotube arrays surface. Oxid Med Cell Longevity 2017:3708048. https://doi.org/10.1155/2017/3708048

219. Zhang J, Li GL, Zhang XR et al (2020) Systematically evaluate the physicochemical property and hemocompatibility of phase dependent $\mathrm{TiO}_{2}$ on medical pure titanium. Surface Coatings Technol 404:126501. https://doi.org/10.1016/j.surfcoat.2020. 126501

220. Salimi E (2019) Superhydrophobic blood-compatible surfaces: state of the art. Int J Polymeric Mater Polymeric Biomater 69(6):363-372. https://doi.org/10.1080/00914037.2019.1570510

221. Cao Y (2019). Engineering therapeutic biomaterials for medical implants. PhD Thesis, University of California, San Francisco, USA.

222. Woodbury JM (2015), Hemocompatibility of polymeric materials for blood-contacting applications. PhD Thesis, Colorado State University, USA. 


\section{Authors and Affiliations}

\section{Masoud Sarraf $^{1,2} \cdot$ Erfan Rezvani Ghomi $^{3}$ [i] $\cdot$ Saeid Alipour ${ }^{2} \cdot$ Seeram Ramakrishna $^{3} \cdot$ Nazatul Liana Sukiman $^{1}$}

$\triangle$ Erfan Rezvani Ghomi erfanrezvani@u.nus.edu

$\triangle$ Seeram Ramakrishna seeram@nus.edu.sg

1 Centre of Advanced Materials, Department of Mechanical Engineering, Faculty of Engineering, University of Malaya, 50603 Kuala Lumpur, Malaysia
2 Department of Materials Science and Engineering, Sharif University of Technology, Azadi Ave., P.O. Box 11365-9466, Tehran, Iran

3 Center for Nanotechnology and Sustainability, Department of Mechanical Engineering, National University of Singapore, Singapore 117581, Singapore 